\title{
The SUMup dataset: compiled measurements of surface mass balance components over ice sheets and sea ice with analysis over Greenland
}

\author{
Lynn Montgomery ${ }^{1}$, Lora Koenig ${ }^{2}$, and Patrick Alexander ${ }^{3,4}$ \\ ${ }^{1}$ Department of Atmospheric and Oceanic Science, University of Colorado, Boulder, CO, USA \\ ${ }^{2}$ National Snow and Ice Data Center, University of Colorado, Boulder, CO, USA \\ ${ }^{3}$ Lamont Doherty Earth Observatory, Columbia University, Palisades, NY, USA \\ ${ }^{4}$ NASA Goddard Institute for Space Studies, 2880 Broadway, New York, NY, USA \\ Correspondence: Lynn Montgomery (lynn.montgomery@ colorado.edu)
}

Received: 19 February 2018 - Discussion started: 7 March 2018

Revised: 5 October 2018 - Accepted: 8 October 2018 - Published: 23 October 2018

\begin{abstract}
Increasing atmospheric temperatures over ice cover affect surface processes, including melt, snowfall, and snow density. Here, we present the Surface Mass Balance and Snow on Sea Ice Working Group (SUMup) dataset, a standardized dataset of Arctic and Antarctic observations of surface mass balance components. The July 2018 SUMup dataset consists of three subdatasets, snow/firn density (https://doi.org/10. 18739/A2JH3D23R), at least near-annually resolved snow accumulation on land ice (https://doi.org/10.18739/ A2DR2P790), and snow depth on sea ice (https://doi.org/10.18739/A2WS8HK6X), to monitor change and improve estimates of surface mass balance. The measurements in this dataset were compiled from field notes, papers, technical reports, and digital files. SUMup is a compiled, community-based dataset that can be and has been used to evaluate modeling efforts and remote sensing retrievals. Active submission of new or past measurements is encouraged. Analysis of the dataset shows that Greenland Ice Sheet density measurements in the top $1 \mathrm{~m}$ do not show a strong relationship with annual temperature. At Summit Station, Greenland, accumulation and surface density measurements vary seasonally with lower values during summer months. The SUMup dataset is a dynamic, living dataset that will be updated and expanded for community use as new measurements are taken and new processes are discovered and quantified.
\end{abstract}

\section{Introduction and background}

Earth's polar regions are warming at an accelerated rate. As increased air temperatures and associated feedbacks with radiative heating persist, the ice cover is changing, particularly at the ice-atmosphere interface (e.g., Vaughan et al., 2003; Serreze and Francis, 2006; Hall et al., 2013). This change is evident in declining Arctic sea ice extent (e.g., RichterMenge et al., 2016) and the recent acceleration of total mass loss from the Greenland Ice Sheet (GrIS) and Antarctic ice sheets (AIS) (e.g., Velicogna et al., 2014; IMBIE Team, 2018), which contributed $\sim 11 \mathrm{~mm}$ to global sea levels between 1992 and 2011 (Shepherd et al., 2012). Surface change is particularly evident over the GrIS. Surface mass balance is defined as snow accumulation, including snowfall, water vapor redeposition, and positive wind redistribution, minus ablation, including melt discharge, negative wind redistribution, evaporation, and sublimation (van den Broeke et al., 2017). In this paper, we use the terminology of accumulation and negative accumulation as we cannot, with our measurements, separate out the components of wind redistribution, sublimation, evaporation, or melt. The GrIS's surface mass balance is dominated by melt, now accounting for more than half of its mass loss (e.g., van Angelen et al., 2013; van den Broeke et al., 2017; Enderlin et al., 2014; Hofer et al., 2017). To understand this change, and the processes driving the change, it is vital to compile measurements from the past and present, and to continue to collect them in the future. 
In 2012, at the Surface Mass Balance and Snow on Sea Ice Working Group (SUMup) meeting, the modeling and remote sensing communities clearly stated to observationalists that the lack of easy-to-access, standardized, in situ measurements hindered scientific achievement. They also emphasized the need for spatially extensive measurements and annual to sub-annual accumulation measurements to coincide with the spatial and temporal scales covered by modeling and remote sensing methods. A public, annual to decadal, standardized time series of measurements was recommended (Koenig et al., 2013). Modeling and remote sensing studies require validation measurements (e.g., Fettweis et al., 2017; Arthern et al., 2006; Burgess et al., 2010; Kuipers Munneke et al., 2015; Koenig et al., 2016), ideally with the model's same spatial (typically tens of kilometers) and temporal (typically sub-annual) resolutions. These observations are needed over large polar regions, which are difficult for an individual researcher to compile. Today, most field measurements for validation are dispersed across multiple data centers/datasets in differing formats. Some previous Arctic and Antarctic studies have compiled large sets of measurements, generally accumulation measurements (e.g., Mock, 1967a, b; Ohmura and Reeh, 1991; Vaughan and Russell, 1997; Favier et al., 2013; US ITASE, Mayewski et al., 2013; Wang et al., 2016; Machguth et al., 2016b; Thomas et al., 2017; Matsuoka et al., 2018), though most cover only a small region of the ice sheet, are not annually resolved, and/or are not publicly available through a data distribution center.

Here, we present the July 2018 SUMup dataset and its three subdatasets: density, accumulation, and snow depth on sea ice. This data paper serves to fully describe the dataset and includes analysis of the data over the GrIS demonstrating how this dataset increases our knowledge of surface mass balance processes by compiling previously dispersed measurements into a standardized dataset. Uses of SUMup include model validation, remote sensing validation and algorithm development, and long-term monitoring efforts. SUMup measurements should not be used to assess individual measurement errors or establish errors on specific retrieval methods. This is because (1) the spatial/temporal variability of snow depth on sea ice is naturally large due atmospheric processes, including accumulation and aeolian processes, further increased by sea ice characteristics such as age, drift, and ridging (e.g., Warren et al., 1999; Sturm et al., 2002), and (2) the spatial/temporal variability of density and accumulation on land ice is also large due to atmospheric processes, including accumulation, temperature, solar radiation and aeolian process, further increased by ice elevation, topography, melt, and water flow processes (e.g., Alley, 1988; Courville et al., 2007; Laepple et al., 2016; Vandecrux et al., 2018). The field measurements in SUMup were not designed to and cannot control this naturally occurring variability.

\section{The SUMup dataset}

\subsection{Overview}

The SUMup dataset is an expandable, communitybased dataset of field measurements of surface mass balance components that is consistent in format, properly described through metadata, and publicly available. The July 2018 SUMup dataset contains three subdatasets that consist of measurements of snow/firn density (https://doi.org/10.18739/A2JH3D23R), snow accumulation on land ice (https://doi.org/10.18739/A2DR2P790), and snow depth on sea ice (https://doi.org/10.18739/A2WS8HK6X). The SUMup dataset is a living document, meant to be expanded as new measurements are taken or previous measurements discovered. The current release of the July 2018 SUMup dataset expands and replaces the previous three smaller releases of July 2013, July 2015, and July 2017. The measurements compiled in SUMup are from the polar regions and most date from 1950 to the present day. Some ice cores and radar data contained both post- and pre- 1950 accumulation measurement and we did not exclude the pre-1950 data in order to keep the records intact. Pre-1950 accumulation estimates represent $\sim 2 \%$ of the accumulation subdataset.

Figure 1 shows the locations of density and accumulation measurements represented by the July 2018 SUMup dataset. Snow depths on sea ice locations are not shown on this map due to the broad spatial sampling. Density and accumulation measurements are often co-located over the ice sheets where ice cores were collected (Fig. 1).

\subsection{Sources}

SUMup measurements were collected, formatted, and compiled primarily through two methods: (1) searching data archives that traditionally host cryospheric data, which included Pangaea (https://www.pangaea.de/), the Arctic Data Center (https://arcticdata.io/), the NOAA's National Climate Data Center (https://www.ncdc.noaa.gov/), and the National Snow and Ice Data Center (https://nsidc.org/), and (2) by asking members of the cryospheric community to contribute field measurements. Keyword searches for the first method include searching for the words "density", "accumulation", and "snow depth on sea ice". For point measurements, annual and subannual accumulation measurements are included. For data from spatially extensive methods (e.g., from radar isochrones), near-annual resolution is required. Various data types are compiled into the SUMup dataset, including handwritten notes, technical reports, and digital files. Each measurement in the SUMup dataset contains a citation to the original source of the data. Based on keyword searches, data for this release, July 2018, should include most relevant measurements available in the data archives listed above posted 


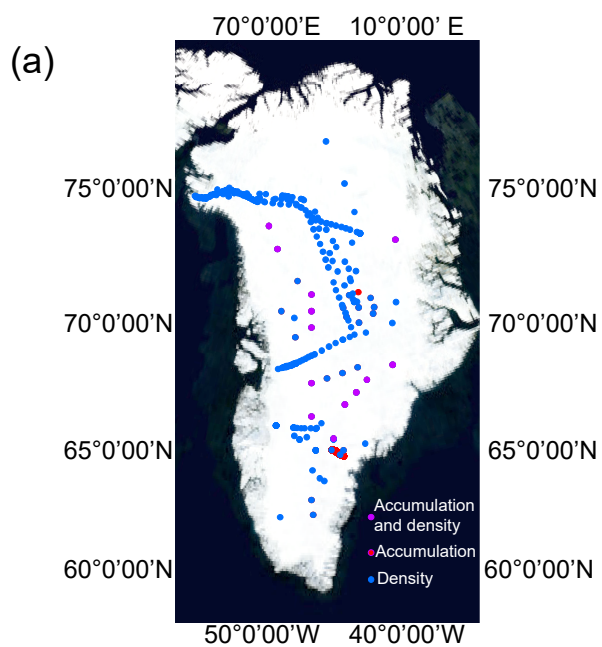

(b)

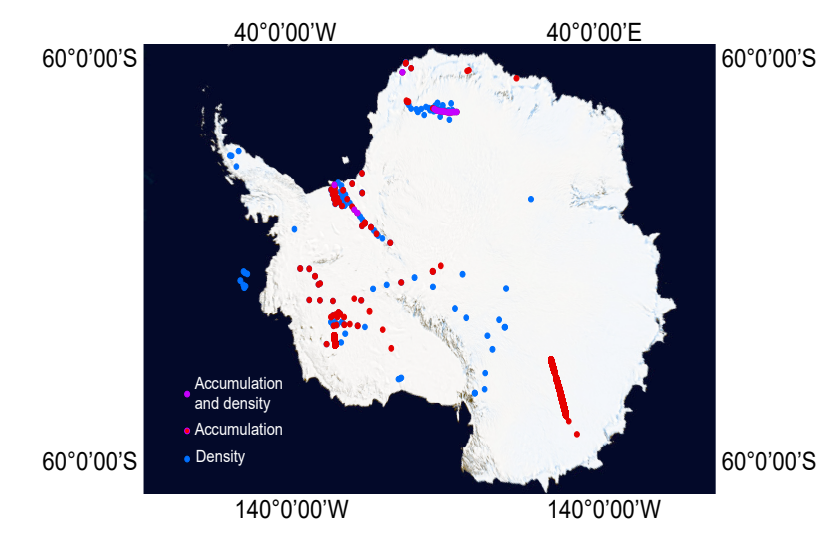

Figure 1. (a) Measurement locations for accumulation (red), snow density (blue), or both (purple) for the SUMup dataset on the GrIS. Snow depth on sea ice data for the Arctic are not shown. (b) Same as above but for the AIS. Locations on sea ice, those in the Bellingshausen Sea, include both snow density and snow depth on sea ice measurements.

before May 2018. It is possible, however, that datasets can be missed by keyword searches, and the community is encouraged to contact the authors directly about any missing datasets that should be included in future releases of SUMup. Specifically, we are working to standardize data from the Japanese Antarctic Research Expedition (JARE) to add in a future release of SUMup.

New and unique data sources are included in the SUMup dataset. Notably, the snow density subdataset includes snow pit data from Carl Benson's Greenland traverses in the early 1950s and data from 1955 that previously had not been digitally scanned (Benson, 2013, 2017). The 1955 notebooks are only archived in the National Snow and Ice Data Center paper archives. The SUMup dataset also includes snow accumulation measurements from Summit Station, Greenland's stake network called the Bamboo Forest (Dibb and Fahnestock, 2004), and corresponding density measurements at monthly temporal resolution (Dibb et al., 2007). Additionally, more widely used data sources are included, such as US International Trans-Antarctic Scientific Expedition (US ITASE, Mayewski et al., 2013) ice cores, the Program for Arctic Regional Climate Assessment (PARCA, MosleyThompson et al., 2001) ice cores, and the Greenland Inland Traverse (GrIT, Hawley et al., 2014) snow pits and ice cores. Section 2.4 provides more details on the specific sources for each of the three subdatasets, including the complete list of all citations.

\subsection{Contributing to the dataset}

The SUMup dataset will continue to expand on an annual basis as new measurements are taken and/or old measurements are discovered. Beyond expanding the current subdatasets, we expect to add additional subdatasets on surface mass balance processes which may include, but are not limited to, snow/ice albedo, snow temperature, and short-wave/longwave radiation measurements. The community is encouraged to contribute data or suggest missing data sources/types to add to SUMup by contacting the authors directly.

\subsection{Structure and metadata}

Each measurement contains common variables, including the date taken, latitude, longitude, surface elevation if on land, the measurement itself, error associated with the measurement, the method by which the measurement was taken, and a citation to which the measurement can be sourced back. By convention, negative latitudes represent south and negative longitudes represent west. For measurements that did not specify a specific month and day for the measurement, but provided only the year ("yyyy"), the date was entered as "yyyy0000". A fill value of -9999 was used for unknown or unmeasured parameters. Measurements can be separated into direct measurements, when the instrument measures the desired parameter directly, and derived measurements, when the instrument measures a parameter related to the primary parameter and uses a known relationship equation to derive the desired measurement. In this paper, we refer to both direct and derived measurements as measurements. Measurement methods are fully listed in each dataset's metadata by number. For clarity, in the density dataset, methods (defined in the readme files) $1-4,6-9$, and 13 are direct measurements (e.g., density cutters, ice core sections), while methods 5, 10-12, and 14-15 are derived measurements (e.g., neutron density probe, X-ray microfocus computer tomography, Gamma-ray attenuation). In the accumulation dataset, 
Table 1. The parameters for each snow density measurement in the SUMup dataset with a brief description and the unit of measurement.

\begin{tabular}{lll}
\hline Column & Description & Unit \\
\hline Date taken & Date the data were taken & yyyymmdd \\
Latitude & Latitude of measurement & Decimal degree \\
Longitude & Longitude of measurement & Decimal degree \\
Start depth & Top depth of the measurement in meters from the snow-air interface (snow surface) & $\mathrm{m}$ \\
Stop depth & Bottom depth of the measurement in meters from the snow-air interface (snow surface) & $\mathrm{m}$ \\
Midpoint depth & Midpoint depth of the measurement in meters from the snow-air interface (snow surface) & $\mathrm{m}$ \\
Density & Snow density measurement & $\mathrm{g} \mathrm{cm}^{-3}$ \\
Error & Uncertainty in density measurement & $\mathrm{g} \mathrm{cm}^{-3}$ \\
Elevation & Elevation above sea level & $\mathrm{m}^{-}$ \\
Method & How the measurement was collected (see metadata for more details) & - \\
Citation & Cited source of data (see metadata for more details) & - \\
\hline
\end{tabular}

methods 1 and 3 are direct measurements (e.g., ice core sections and stake measurements), while method 2 is derived (radar isochrones). All snow depth on sea ice measurements are direct measurements. Uncertainties of measurements were only recorded if provided with the original measurement. More detail on general uncertainty for measurement methods used in SUMup is available for density cutters (Conger and McClung, 2009), a neutron density probe (Morris, 2008), density and conductivity mixed permittivity (DECOMP) (Wilhelms, 2005), and gamma-ray attenuation (Wilhelms, 1996). These can be applied to measurements as appropriate for individual scientific application.

If any of the original measurements/metadata were unclear or non-existent, the original author of the data was contacted to clarify inconsistencies or questions. Snow density measurements that exceeded a physically plausible range from $<0$ and $>1000 \mathrm{~kg} \mathrm{~m}^{3}$ were rejected. Specific details on measurement methods and citations for each subdataset are included in the SUMup metadata files hosted at the Arctic Data Center and described below.

\subsubsection{Snow density}

The snow/firn density subdataset of SUMup is the largest, containing over 2100000 unique measurements of density at different depths (Fig. 1). Table 1 describes the parameters for each density measurement. The measurement methods include density cutters of different sizes (generally from 100 to $1000 \mathrm{~cm}^{3}$ ) used in snow pits, gravitational methods used on ice core sections, neutron-density methods performed in boreholes, X-ray microfocus computer tomography performed on snow samples, gamma-ray attenuation in boreholes, pycnometers used on snow samples, optical televiewer (OPTV) borehole logging, and DECOMP. The majority of the observations $(\sim 76 \%$ ) come from Greenland ice cores or snow pits (Renaud, 1959; Ohmura, 1991, 1992; Alley, 1999; Bolzan and Strobel, 1999a-g, 2001a, b; Miller and Schwager, 2000a, b; Wilhelms, 2000a-d; Mosley-Thompson et al., 2001; Bales et al., 2001; Conway, 2003; Dibb and
Fahnestock, 2004; Dibb et al., 2007; Harper et al., 2012; Benson, 2013, 2017; Miège et al., 2013; Hawley et al., 2014; Koenig et al., 2014; Baker, 2016; Chellman, 2016; Machguth et al., 2016a; Mayewski and Whitlow, 2009a-d; Schaller et al., 2016, 2017; Cooper et al., 2018; MacFerrin et al., 2018). Antarctic measurements comprise $\sim 23 \%$ of the snow density subdataset and are predominantly from ice cores (Graf et al., 1988a-q, 1999n-y, 2002a-o; Wagenbach et al., 1994b-d; Gerland and Wilhelms, 1999; Oerter et al., 1999a-h, 2000aj; Oerter, 2002, 2008p-ae; Schlosser and Oerter, 2002c; Graf and Oerter, 2006z-au; Albert, 2007; Fernandoy et al., 2010ac; Kreutz et al., 2011; Lewis et al., 2011; Koenig and Brucker, 2011; Mayewski et al., 2013; Hubbard et al., 2013; Medley et al., 2013; Schaller et al., 2017). The depths of the density measurements were recorded using two different methods, either the top and bottom depth or a midpoint depth. While a midpoint can be determined uniquely from the top and bottom depths, the top and bottom cannot always be determined from the midpoint and researchers need to determine how to standardize or interpolate the depths for their specific applications.

\subsubsection{Snow accumulation on land ice}

The snow accumulation on land ice subdataset of SUMup contains over 230000 unique measurements (Fig. 1). Table 2 describes the parameters for each accumulation measurement. The measurement methods include ice cores and/or boreholes, snow pits, radar isochrones, and stake measurements. Arctic measurements are predominantly from ice cores and stake measurements and include one radar nearannual transect in southeastern Greenland (Bolzan and Strobel, 1999a-g, 2001a, b; Mosley-Thompson et al., 2001; Dibb and Fahnestock, 2004; Miège et al., 2013). The Antarctic measurements are predominantly from ice cores and include two radar transects, one in West Antarctica and one in East Antarctica (Wagenbach et al., 1994a; Graf et al., 1999a-m; Schlosser and Oerter, 2002a, b; Spikes et al., 2005; Graf and Oerter, 2006a-y; Anschütz and Oerter, 2007a-f; Banta 
Table 2. The parameters for each snow accumulation measurement on land ice in the SUMup dataset with a brief description and the unit of measurement.

\begin{tabular}{lll}
\hline Column & Description & Unit \\
\hline Date taken & Date the data were taken & yyyymmdd \\
Latitude & Latitude of measurement & Decimal degree \\
Longitude & Longitude of measurement & Decimal degree \\
Start year & First year of measurement if accumulation is not annual & year \\
End year & Last year of measurement if accumulation is not annual & year \\
Year & Year of accumulation if accumulation is annual & year \\
Accumulation & Accumulation in meters of water equivalent per year & m w.e. $\mathrm{a}^{-1}$ \\
Error & Uncertainty in measurement & $\mathrm{m}$ w.e. $\mathrm{a}^{-1}$ \\
Elevation & Elevation above sea level & $\mathrm{m}$ \\
Radar horizontal resolution & Horizontal resolution of radar data along track & $\mathrm{m}$ \\
Method & How the measurement was collected (see metadata for more details) & - \\
Name & Name of field campaign (see metadata for more details) & - \\
Citation & Cited source of data (see metadata for more details) & - \\
\hline
\end{tabular}

et al., 2008; Oerter, 2008a-o; Fernandoy et al., 2010a-c; Ferris et al., 2011; Verfaillie et al., 2012; Burgener et al., 2013; Mayewski et al., 2013; Medley et al., 2013; Philippe et al., 2016). In most instances accumulation (in water equivalent, w.e.) was provided in the original measurement; however, the Summit Station, Greenland, Bamboo Forest measurements consist of weekly surface height change at 100 stakes along with snow density (Dibb and Fahnestock, 2004). We multiplied the height change by the coincident snow density and averaged across all stakes to get accumulation measurements for SUMup. Similarly, the Bolzan and Strobel data (1999a-g, 2001a, b) provided a snow pit depth, year, and density that were converted to accumulation. Most of the accumulation measurements are annually resolved, with the major exceptions being the radar measurements, which are approximately decadal, and Bamboo Forest data, which are approximately monthly.

\subsubsection{Snow depth on sea ice}

The snow depth on sea ice subdataset is the sparsest within SUMup, with $\sim 92000$ unique measurements. Table 3 describes the parameters for each snow depth measurement. The measurement methods include rulers, magnaprobes, avalanche probes, and snow corers. The Arctic measurements span from 1990 to 2018 and cover areas off the coast of Finland (Eero Rinne, personal communication, 2012), near Kotzebue Sound, and Utqiagvik, Alaska (Turner et al., 2018a, b), Eureka and Nunavut, Canada, from the Environment and Climate Change Canada campaign (ECCC 2014) (King et al., 2015), near Ellesmere Island from the CryoSat-2 Validation Experiment (CryoVEX) (Haas et al., 2017), Elson Lagoon from the Bromine, Ozones, and Mercury Experiment (BROMEX) (Webster et al., 2014), and Prudhoe Bay, Alaska, from the Ice and Climate Experiment (ICEX 2011) (Gardner et al., 2012). The Antarctic ob- servations are from the Sea Ice Mass Balance in the Antarctic (SIMBA) dataset which was collected from the research vessel/ice breaker N.B. Palmer in September and October 2007 in the Bellingshausen Sea (Lewis et al., 2011). We note that large, standardized datasets of radar-derived snow depth on sea ice are available through the IceBridge Sea Ice Freeboard, Snow Depth and Thickness product and similar products derived from the IceBridge Snow Radar (Kurtz, 2012; Kwok et al., 2017). These snow depths from Operation IceBridge are no longer included in the SUMup dataset as of July 2015, but are included in a separate archive due to their size.

\section{Spatial and temporal data analysis}

The goal of the SUMup dataset is that it can be broadly used by the scientific community for a variety of research studies. Tables 4 and 5 provide the basic descriptive statistics for each subdataset for the Arctic and Antarctic, respectively. These tables provide a coarse overview of the data; however, when using the SUMup datasets, subsetting by location, time, depth, etc. will likely be required for specific applications. The minimum value for accumulation in the Arctic is $-0.004 \mathrm{~m}$ w.e. $\mathrm{a}^{-1}$, which represents an ablation value from monthly Bamboo Forest measurements at Summit Station, Greenland. In total, there are 5 months, all occurring in separate years, with small negative accumulation measurements from Summit Station. These negative accumulation measurements are likely due to the ablation processes of sublimation or negative wind redistribution; however, a stake measurement alone cannot determine the underlying process of a surface height change.

Field data collected over the vast polar regions have spatial and temporal sampling bias, as the time, cost, and logistics to systematically sample these regions is unreasonable. We describe the SUMup dataset here to elucidate possible bias. All the measurements in SUMup, with the exception of one loca- 
Table 3. The parameters for each snow depth on sea ice measurement in the SUMup dataset with a brief description and the unit of measurement.

\begin{tabular}{|c|c|c|}
\hline Column & Description & Unit \\
\hline Date taken & Date the data were taken & yyyymmdd \\
\hline Latitude & Latitude of measurement & Decimal degree \\
\hline Longitude & Longitude of measurement & Decimal degree \\
\hline Distance along transect & $\begin{array}{l}\text { Distance along a transect of in situ snow depth measurements over sea } \\
\text { ice from the initial lat, long. Used for snow-depth measurements; } \\
\text { point by point lat, long was not recorded. }\end{array}$ & $\mathrm{m}$ \\
\hline Snow depth & Snow depth measurement & $\mathrm{m}$ \\
\hline Snow depth error & Uncertainty in snow depth measurement & $\mathrm{m}$ \\
\hline Density taken & If density measurement was taken $=1$, if no measurement $=0$. & - \\
\hline Sea ice thickness & Sea ice thickness measurement & $\mathrm{m}$ \\
\hline Sea ice thickness error & Uncertainty in sea ice thickness measurement & $\mathrm{m}$ \\
\hline Sea ice type & $1=$ first year ice, $2=$ multilayer ice,$-9999=$ unknown & - \\
\hline Sea ice freeboard & Sea ice freeboard measurement & $\mathrm{m}$ \\
\hline Sea ice freeboard error & Uncertainty in sea ice freeboard & $\mathrm{m}$ \\
\hline Snow ice thickness & Snow ice thickness measurement & $\mathrm{m}$ \\
\hline Snow ice thickness error & Uncertainty in snow ice thickness measurement & $\mathrm{m}$ \\
\hline Radar horizontal resolution & Horizontal resolution of radar data along track & $\mathrm{m}$ \\
\hline Method & How the measurement was collected (see metadata for more details) & - \\
\hline Citation & Cited source of data (see metadata for more details) & - \\
\hline
\end{tabular}

Table 4. The descriptive statistics for all of the Arctic measurements in SUMup, including the minimum (min), maximum (max), mean, median, standard deviation (SD), and number of measurements $(N)$.

\begin{tabular}{lrrr}
\hline Statistic & $\begin{array}{r}\text { Snow } \\
\text { density } \\
\left(\mathrm{g} \mathrm{cm}^{-3}\right)\end{array}$ & $\begin{array}{r}\text { Accumulation } \\
\text { on land ice } \\
\left(\mathrm{m} \mathrm{w.e.}^{-1}\right)\end{array}$ & $\begin{array}{r}\text { Snow depth } \\
\text { on sea ice } \\
(\mathrm{m})\end{array}$ \\
\hline min & 0.0003 & -0.004 & 0.000 \\
max & 0.970 & 2.257 & 1.2180 \\
mean & 0.4717 & 1.040 & 0.1852 \\
median & 0.3792 & 1.034 & 0.1560 \\
SD & 0.2037 & 0.171 & 0.1505 \\
$N$ & 1642313 & 144060 & 89536 \\
\hline
\end{tabular}

Table 5. The descriptive statistics for all of the Antarctic measurements in SUMup, including the minimum (min), maximum (max), mean, median, standard deviation (SD), and number of measurements $(N)$.

\begin{tabular}{lrrr}
\hline Statistic & $\begin{array}{r}\text { Snow } \\
\text { density } \\
\left(\mathrm{g} \mathrm{cm}^{-3}\right)\end{array}$ & $\begin{array}{r}\text { Accumulation } \\
\text { on land ice } \\
\left(\mathrm{m} \mathrm{w.e.}^{-1}\right)\end{array}$ & $\begin{array}{r}\text { Snow depth } \\
\text { on sea ice } \\
(\mathrm{m})\end{array}$ \\
\hline min & 0.1008 & 0.0179 & 0.000 \\
max & 0.9379 & 1.3980 & 1.900 \\
mean & 0.5568 & 0.1306 & 0.479 \\
median & 0.4252 & 0.1327 & 0.430 \\
SD & 0.2272 & 0.0585 & 0.363 \\
$N$ & 519069 & 88020 & 3176 \\
\hline
\end{tabular}

tion, were collected during the spring/summer season for that polar region, roughly April through August for the Arctic and October through February for the Antarctic. Summit Station, Greenland, the only GrIS station with year-round operations, is the one exception in the dataset where temporally consistent, year-round measurements are taken. Below, we summarize the spatial and temporal distributions of the SUMup dataset by subdatasets. For the two largest subdatasets, snow density and accumulation, we present analysis over the GrIS (Sect. 3.4). This analysis is meant to be an introduction to the dataset and is not exhaustive. We encourage the community to continue to use and more fully exploit this dataset. Figure 2 provides a bar graph showing the measurement methods that make up each subdataset showing that measurement techniques with high spatial (e.g., radar isochrones) and high depth (e.g., neutron probes) resolution dominate the number of measurements in a subdataset; however, they often have limited spatial coverage with respect to the entire region.

\subsection{Snow density}

Measurements were compiled of snow/firn density that cover $\sim 306$ sites in the Arctic and $\sim 164$ sites across Antarctica (Fig. 1). The majority of these measurements come from snow pits and ice cores on the GrIS and AIS; however, there are seven locations of snow density measurements on sea ice in the Bellinghausen Sea. Here, we analyze only the ice sheet measurements.

The density subdataset is dominated ( $98 \%$ of data) by high vertical depth resolution measurements (millimeter scale for $\sim 100 \mathrm{~m}$ ) from X-ray microfocus computer tomography, 
(a) Density dataset

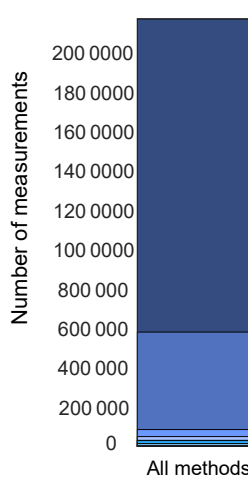

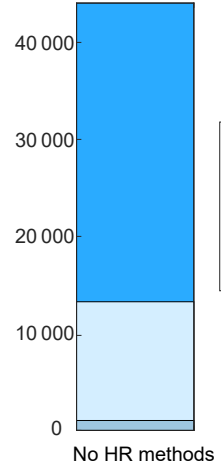

(b) Accumulation dataset
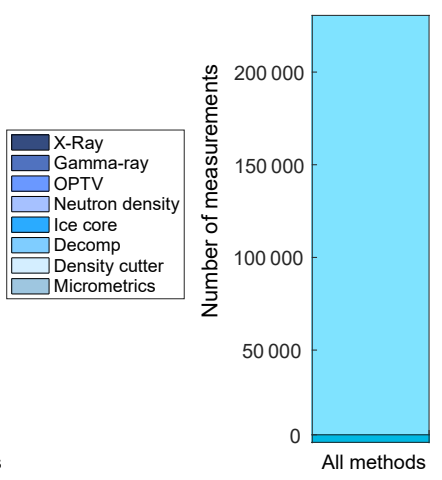

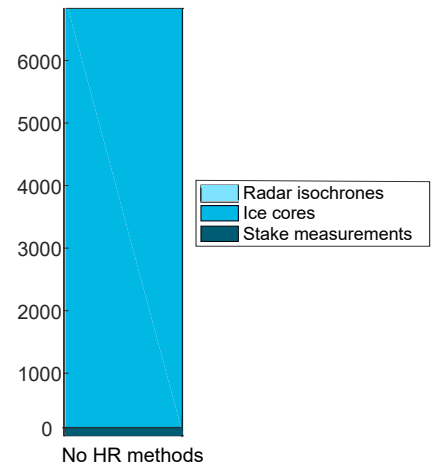

Figure 2. Bar charts showing the measurement methods in the (a) density subdataset and (b) accumulation subdataset. The left bar in each plot shows the distribution of all methods and the right bar shows the distribution of methods excluding the high-resolution spatial (accumulation) or depth (density) measurements.
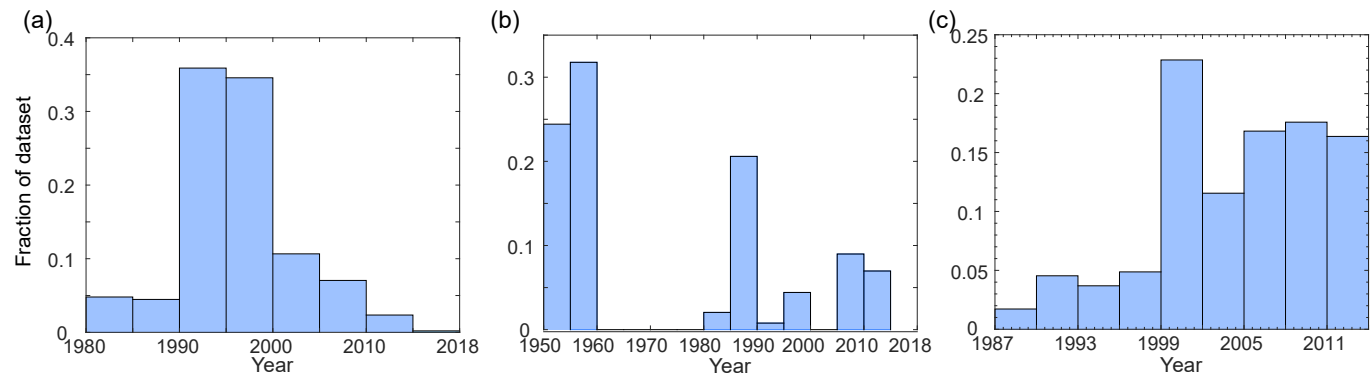

Figure 3. Histograms showing the date taken and associated fraction of the density dataset for (a) Antarctica, (b) Greenland excluding Summit Station, and (c) Summit Station. Please note the different timescales on the $x$ axis.

neutron density methods, gamma-ray attenuation, OPTV, and DECOMP measurements taken on cores or in boreholes at 24 locations in northern Greenland (Wilhelms, 2000a-d; Miller and Schwager, 2000a, b; Schaller et al., 2016, 2017) and 44 locations from Antarctica (Gerland and Wilhelms, 1999; Oerter et al., 1999a-h, 2000a-j; Graf et al., 2002a-o; Kreutz et al., 2011; Hubbard et al., 2013; Schaller et al., 2017) (Fig. 2). Because of the high depth resolution of these measurements at millimeter scale, compared to more typical density measurements at decimeter to meter scale, these data saturate histogram representations of this subdataset. For this reason, we do not use these measurements in the following analysis, thus providing a more realistic overview of the fraction of the density measurements taken throughout time and space.

Figure 3 provides histograms showing the fraction of density measurements taken by year for Antarctica, Greenland excluding Summit Station, and Summit Station. (Summit Station was defined as a bounding box of 72 to $73^{\circ} \mathrm{N}$ and 38 to $39^{\circ}$ W.) Summit Station measurements are plotted separately because this unique site provides the only location on the GrIS with year-round measurements over multiple years. The histograms for Antarctica and Greenland show spikes through time related to major collection campaigns. Antarctic density measurements peak from 1990 to 2000 related to a large amount of ice cores taken in Dronning Maud Land and the Filchner Ronne Ice Shelf (Oerter et al., 1999a-g, 2000ai; Graf et al., 2002a-o). Greenland measurements first peak in the early 1950s with measurements from Benson's traverses. They peak again in the late 1980s through the 1990s related to the activities surrounding GISP2 and PARCA ice cores (Alley, 1999; Bolzan and Strobel, 1999a-g; MosleyThompson et al., 2001) and peak for third time in the early 2010s with the Greenland Inland Traverse and the Arctic Circle Traverse cores (Miège et al., 2013; Hawley et al., 2014). Measurements from Summit Station steadily increase in time from 1987 to 2014 with a slight peak in the late 1990s and early 2000s related to additional measurements surrounding the PARCA and GISP2 projects (Dibb and Fahnestock, 2004; Alley, 1999).

Figure 4 provides an overview of the distributions of depths sampled by the density subdataset. Overall, the number of measurements decreases with depth. The Antarctic measurements decrease less uniformly with depth, which is related to the larger number of deeper ice cores. The majority of Greenland measurements are above $5 \mathrm{~m}$ and there are very 
(a)

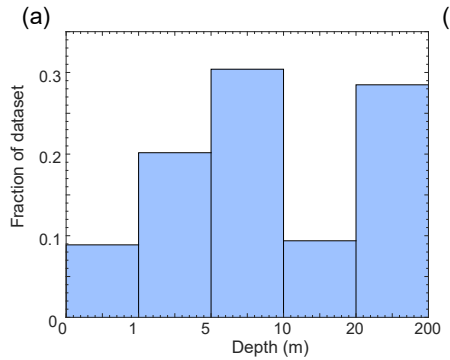

(b)

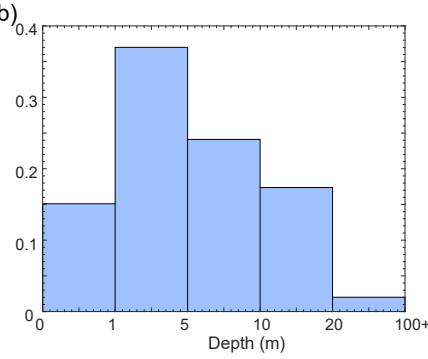

(c)

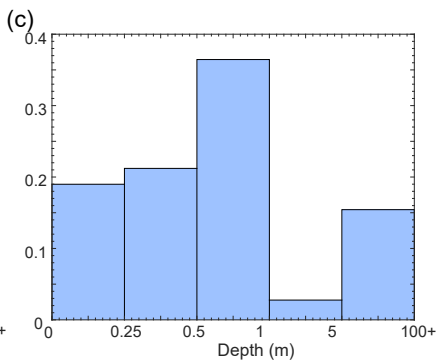

Figure 4. Histograms showing the fraction of the density dataset by mid-point sampling depths for (a) Antarctica, (b) Greenland excluding Summit Station, and (c) Summit Station.
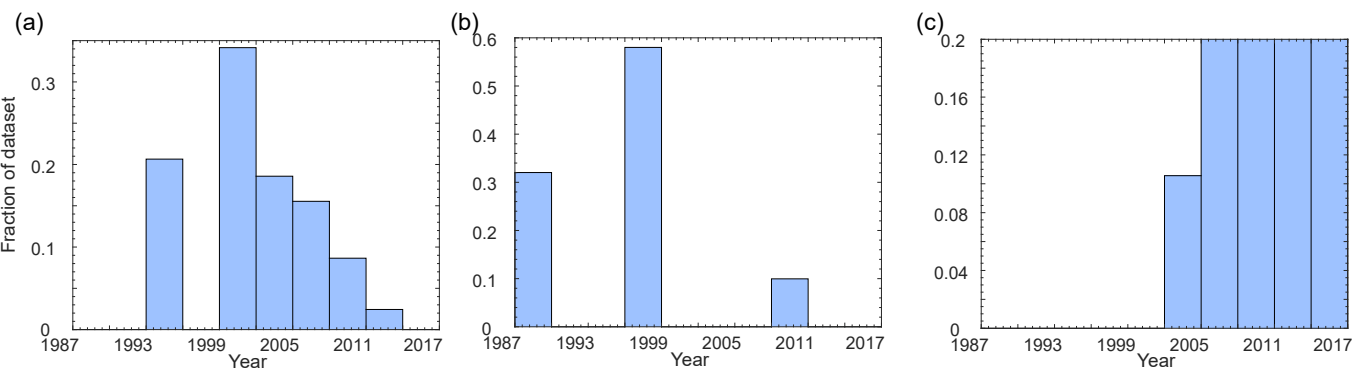

Figure 5. Histograms showing the date taken and associated fraction of the accumulation dataset for each area examined: (a) Antarctica, (b) Greenland excluding Summit Station, and (c) Summit Station.

few measurements below $20 \mathrm{~m}$, demonstrating the large number of shallow cores collected across Greenland. At Summit Station, the majority of the measurements are taken above $1 \mathrm{~m}$ as a result of systematic tasking to $\operatorname{dig} \sim 1 \mathrm{~m}$ snow pits at approximately monthly intervals since 2003 . The deep $100 \mathrm{~m}$ plus measurements at Summit come from the GISP2 ice core (Alley, 1999).

\subsection{Accumulation}

Measurements of accumulation over land ice were taken at $\sim 91$ locations in Antarctica and $\sim 36$ locations in Greenland. These include two radar traverses that span several hundreds of kilometers in Antarctica, and a $75 \mathrm{~km}$ radar traverse in southeastern Greenland (Fig. 1).

In total, $62 \%$ of the accumulation measurements are from the Arctic, all within Greenland, with $<1 \%$ of the overall measurements coming from Summit Station. The Antarctic contributes the remaining $38 \%$ of the measurements. The accumulation subdataset is dominated ( $96 \%$ of data, Fig. 2) by high horizontal spatial resolution (tens of meters) radar accumulation measurements taken from three ice sheet transects (Fig. 1). These data saturate histogram representations of this subdataset and are not used in the following analysis to provide a more realistic overview of the fraction of accumulation measurements taken throughout time and space.

Figure 5 provides histograms showing the fraction of accumulation measurements taken by year for Antarctica, Green- land excluding Summit Station, and Summit Station. Year, in this case, is defined as the year in which the ice core, snow pit, etc. were collected/dug. The histograms for the Antarctic and Greenland show sporadic spikes through time corresponding to major collection campaigns, similar to yet more exaggerated than in the density subdataset. Antarctic measurements peak in the early 2000s when US ITASE ice cores were collected in West Antarctica (Mayewski et al., 2013). Greenland accumulation measurements peak in the late 1980s with ice cores preparing for the GISP2 core and in the late 1990s when the PARCA ice cores (MosleyThompson et al., 2001) were collected. Summit Station has a constant monthly collection of accumulation measurements from August 2003 to August 2016 from the Bamboo Forest measurements (Dibb and Fahnestock, 2004) and represents the only year-round collection of accumulation measurements in the SUMup dataset.

While understanding that the date when accumulation measurements are taken is important, it is also important to understand the year represented by a sample, corresponding to the depth. Figure 6 provides the distribution of years when annual accumulation was measured from 1950 to present. Antarctica has a relatively even distribution of accumulation measurements until 2000 when the number of samples decreases. This decrease is due to the fact that many of the cores collected by US ITASE from 2006 to 2008 in East Antarctica could not be dated to determine accumulation and also shows that most of the firn cores collected date back 

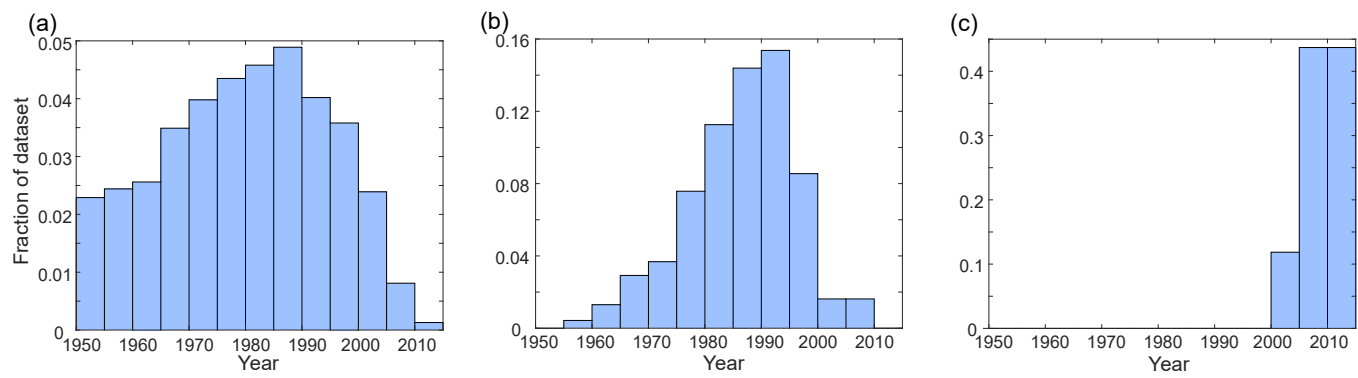

Figure 6. Histograms showing the fraction of accumulation measurements by year for (a) Antarctica, (b) Greenland excluding Summit Station, and (c) Summit Station. Dates are only shown from 1950 forward.

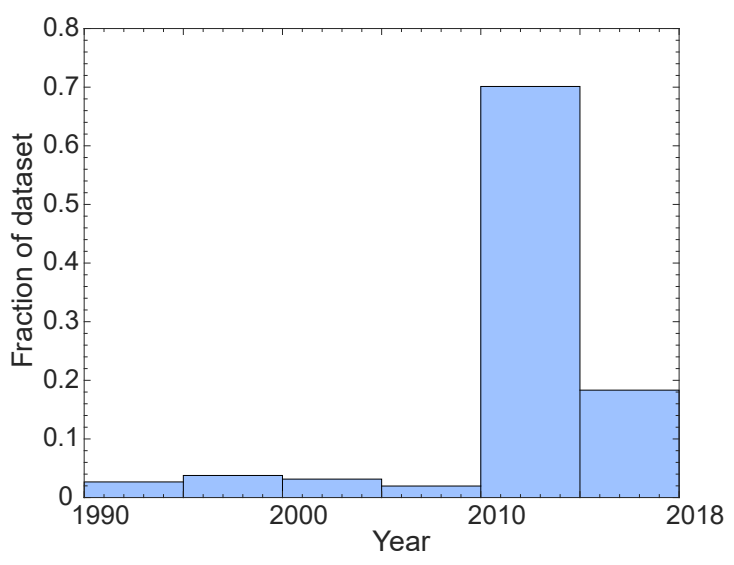

Figure 7. Histogram showing the fraction of snow depth on sea ice measurements by year.

to 1950 or later. The Greenland accumulation measurements peak between 1980 and 2000. The mostly shallow ice cores in Greenland, and relatively higher accumulation rates compared to Antarctica, result in less data from 1950 to 1980 in the ice cores. The sharp decline in the 2000s is due to a lack of coring efforts that occurred during that decade in Greenland. Summit Station has a consistent year-round sampling of accumulation from 2003 to 2016 . These systematic measurements significantly outnumber the single measurements per year collected from ice cores at Summit Station that sample the decades before 2000 .

\subsection{Snow depth on sea ice}

The $\sim 92000$ measurements of snow depth on sea ice are mostly from the Arctic, representing $97 \%$ of the measurements, and the Antarctic represents the remaining 3\%. The Arctic measurements span from 1990 to 2018 (Fig. 7), while the Antarctic measurements are from 2007. The majority of the observations are from 2010 to 2018, including the CryoVEX 2017, ICEX 2011, BROMEX, and Environment and Climate Change Canada (ECCC) 2014 Snow on Sea Ice campaigns.

\subsection{Analysis over the Greenland Ice Sheet}

Recent warming over the GrIS, including a melt event in 2012 that covered nearly the entire surface (Nghiem et al., 2012), has increased both snow density and snow accumulation in recent decades (e.g., Morris and Wingham, 2014; Machguth et al., 2016a; Overly et al., 2016). Improved measurements, or models, of density and its evolution with time are needed to reduce uncertainties when converting altimetry measurements into total ice sheet mass balance using altimetry (e.g., Zwally and Jun, 2002; Shepherd et al., 2012) and for converting radar isochrones into measurements of accumulation (e.g., Koenig et al., 2016). Many models use mean annual temperature and accumulation to model the spatial and temporal evolution of density (e.g., Herron and Langway, 1980; Reeh et al., 2005; Kuipers Munneke et al., 2015). Some studies, however, show that density models generally underestimate surface $(<1 \mathrm{~m}$ depth) density measurements (Koenig et al., 2016), while other studies point to the importance of the surface boundary condition for density models when comparing to measurements (Kuipers Munneke et al., 2015; Bellaire et al., 2017). Fausto et al. (2018) find mean annual temperature is a poor predictor of snow density from 0 to $10 \mathrm{~cm}$ depth. Here, we look more closely at the density and accumulation measurements within the SUMup dataset over the GrIS and their sampling distributions with respect to temperature, elevation, and latitude.

\subsubsection{Greenland density distributions with elevation, latitude, and temperature}

Figure 8 shows the distribution of density measurements with elevation and latitude compared to the total distribution of elevations and latitudes for the entire GrIS. The fraction of the elevation at $250 \mathrm{~m}$ bins (red line of Fig. 8) for the Greenland Ice Sheet is derived from the CryoSat-2 Greenland digital elevation model (DEM; Helm et al., 2014a, bv). Figure 8 uses similar graphing techniques to those of Fausto et al. (2018) to clearly show sampling bias in the observation dataset. If there were no sampling bias, the fraction of measurements would be similar to the fraction of values from the DEM. This is not the case. For elevation (Fig. 8a) we see that el- 
(a)

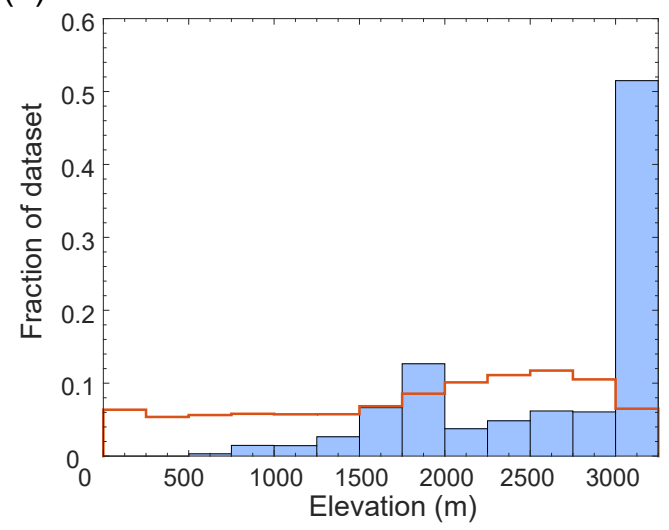

(b)

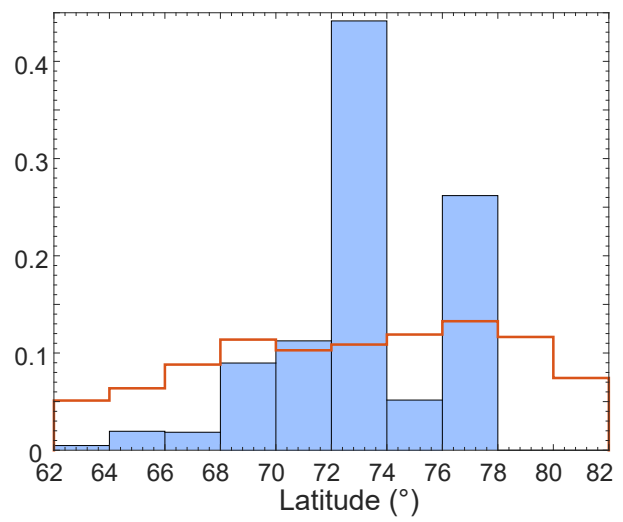

Figure 8. (a) Histogram showing the fraction of density subdataset by elevation. Red line is the fraction of elevations for the entire GrIS from the CryoSat-2 DEM. (b) Histogram showing the fraction of density dataset by latitude. Red line is the fraction of latitudes for the entire GrIS.

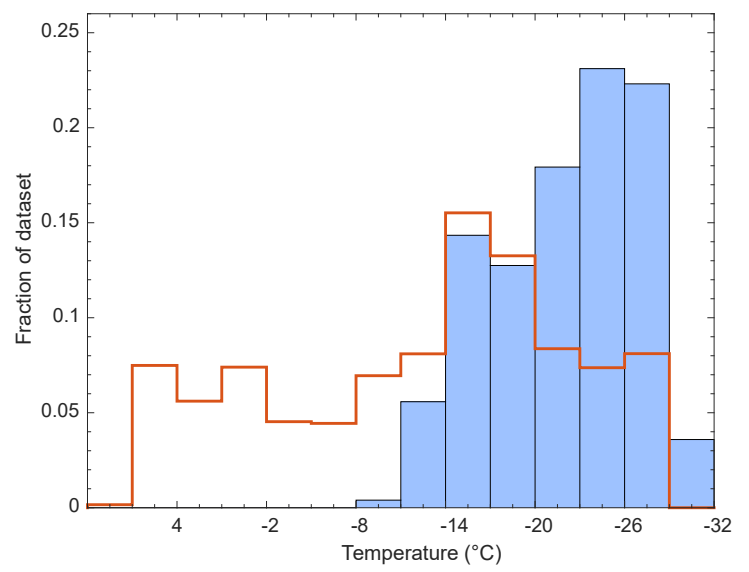

Figure 9. Histogram showing the fraction of the density subdataset by modeled $3 \mathrm{~m}$ annual air temperature. Red line shows 1990-2015 annual average MAR3.5 model $3 \mathrm{~m}$ air temperature distribution for each grid cell across the ice sheet.

evations below $3000 \mathrm{~m}$ are undersampled, with the exception of the $1750-2000 \mathrm{~m}$ bin, and elevations above $3000 \mathrm{~m}$ are largely oversampled. The measurements are therefore biased to higher, inland elevations which, if averaged, would likely cause a low bias in sampled densities. Figure $8 \mathrm{~b}$ shows that our dataset is sampled best over central Greenland. More measurements are required from lower elevations and southern $\left(<70^{\circ} \mathrm{N}\right)$ and northern $\left(>78^{\circ} \mathrm{N}\right)$ latitudes to fill the gaps in the current dataset and reduce spatial bias.

Because mean annual air temperature is a parameter often used to model density (e.g., Herron and Langway, 1980; Reeh et al., 2005), Fig. 9 shows the distribution of density measurements in Greenland in relation to $3 \mathrm{~m}$ mean annual air temperature estimated by the Modèle Atmosphérique Régional (MAR) model version 3.5 (Fettweis et al., 2013) with a horizontal resolution of $25 \mathrm{~km}$. We used the National Centers for Environmental Prediction-National Center for Atmospheric Research Reanalysis version 1 (NCEP-NCARv1) forced MAR 3.5 simulation (run from 1948 to 2015) to find the mean annual $3 \mathrm{~m}$ air temperature for the year corresponding to when the density measurement was taken. The NCEP-NCAR forcing was chosen because it is more reliable than ERA forcings (Fettweis et al., 2017). The red line in Fig. 9 shows the distribution of annual average temperatures (derived from 1990 to 2015) for the entire GrIS. Figure 9 clearly shows a preferential sampling of GrIS regions with lower temperatures. Cold temperatures $\left(-20^{\circ} \mathrm{C}\right.$ and below) are oversampled in the density dataset, while temperatures above $-14{ }^{\circ} \mathrm{C}$, which make up $\sim 30 \%$ of the GrIS, make up less than $6 \%$ of the sampled densities. As with elevation, the density sampling distribution by mean annual temperatures likely results in a low-density bias when trying to characterize the entire GrIS. In general, the density measurements in SUMup across the GrIS oversample cooler, inland regions and undersample warmer, coastal regions.

Figure 10 plots all sites in Greenland with density measurements coincidently sampled to depths of 10, 25, 50, and $100 \mathrm{~cm}$ compared to the mean annual temperature. No clear relationship (Pearson correlation coefficient, $R^{2}=0$ to 0.137 ) between mean annual temperature and density is seen in our data until $\sim 1 \mathrm{~m}$ depth $\left(R^{2}=0.272\right)$ where higher temperatures correspond to higher density. This result suggests that in the top $1 \mathrm{~m}$ of snow/firn on the GrIS, in the colder, more inland areas, temperature may not be the primary variable leading to densification. Solar radiation, layering in firn, and wind processes (e.g., Liston et al., 2007; Hörhold et al., 2011) are likely important in these regions and require snow density models that account for these processes. Due to the spatial sampling bias in this dataset, melt processes are likely not a primary process in determining snow density 


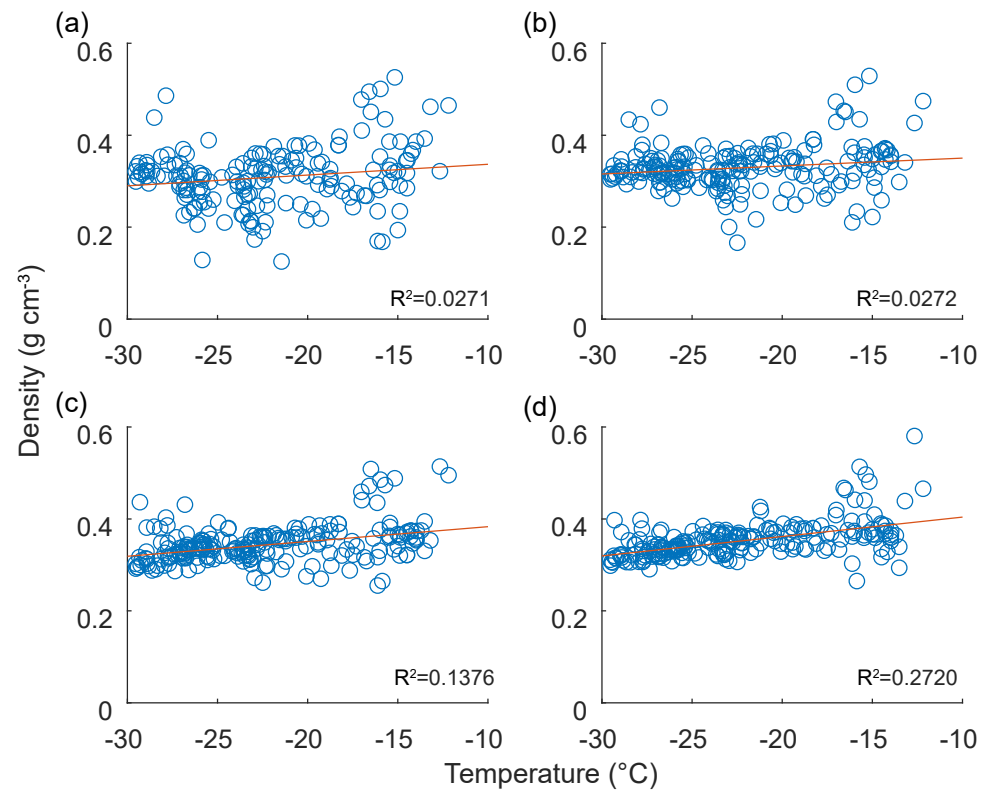

Figure 10. Scatterplot showing the MAR 3.5 modeled mean annual $3 \mathrm{~m}$ air temperature in the year the density was measured compared to the mean density in the top (a) $10 \mathrm{~cm}$, (b) $25 \mathrm{~cm}$, (c) $50 \mathrm{~cm}$, and (d) $100 \mathrm{~cm}$.

(a)

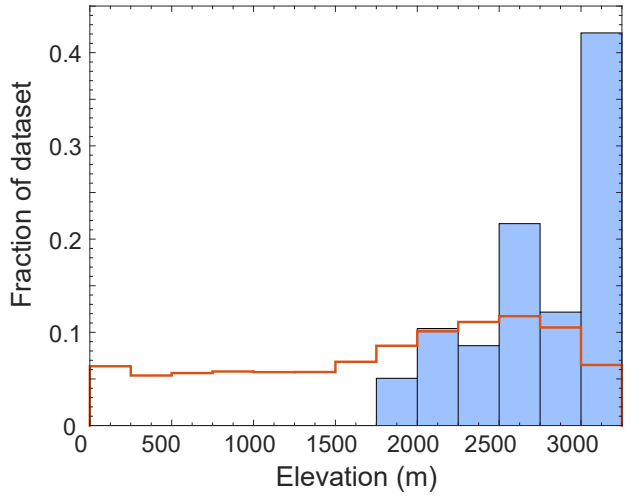

(b)

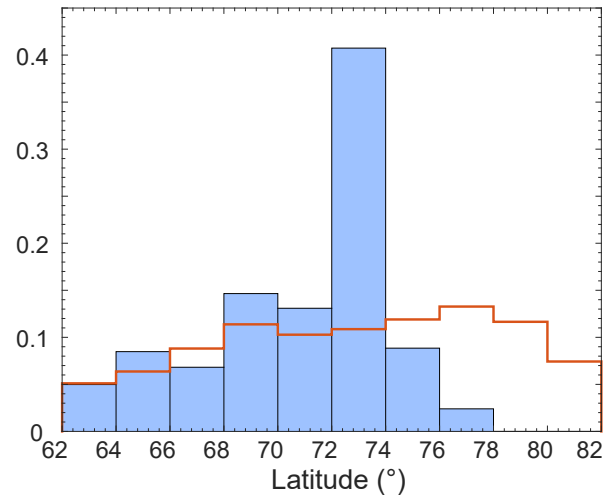

Figure 11. (a) Histogram showing the fraction of the accumulation subdataset by elevation. Red line is the fraction of elevations for the entire GrIS from CryoSat-2 DEM. (b) Histogram showing the fraction of the accumulation dataset by latitude. Red line is the fraction of latitudes for the entire GrIS.

for these measurements; however, melt processes will contribute more in the future (Nghiem et al., 2012; McGrath et al., 2013).

\subsubsection{Accumulation distributions with elevation and latitude}

Snowfall over the GrIS can also be parameterized by elevation and latitude. Figure 11 shows the distributions of the accumulation measurements over the GrIS by elevation and latitude. As with the density measurements the accumulation measurements all come from high elevations on the GrIS $(>1750 \mathrm{~m})$, with the highest elevations $(>3000 \mathrm{~m})$ be- ing largely oversampled. The sampling across latitudes is the most evenly distributed; however, latitudes above $78^{\circ} \mathrm{N}$ represent a gap in the dataset. We do not compare the accumulation subdataset with mean annual temperatures here because each year of accumulation has a different mean annual temperature associated with it. We deem it beyond the scope of this analysis and suggest this as a future study that could be researched using the SUMup dataset. 


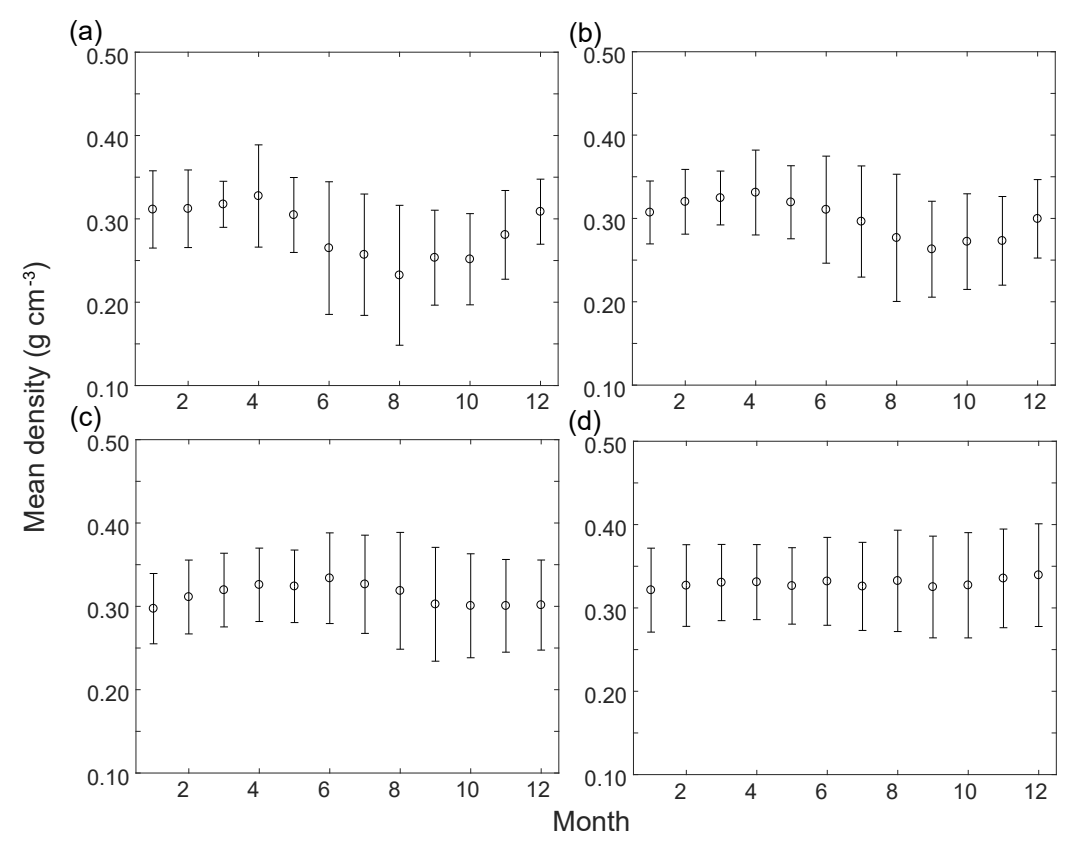

Figure 12. Plot of mean density (circle) and \pm 1 standard deviation (whiskers) for each month at Summit Station, Greenland, for (a) $10 \mathrm{~cm}$, (b) $25 \mathrm{~cm}$, (c) $50 \mathrm{~cm}$, and (d) $100 \mathrm{~cm}$.

\subsubsection{Year-round density and accumulation measurements from Summit Station}

Summit Station is the only site in the dataset, and on the GrIS, that has been systematically sampled for density and accumulation on a nearly monthly basis. Hence, it is the only location on the GrIS to watch the long-term, decadal, seasonal evolution of snow surface density. Figure 12 shows the monthly mean surface density to depths of $10,25,50$, and $100 \mathrm{~cm}$. A seasonal cycle is evident in the 10 and $25 \mathrm{~cm}$ depth mean densities with a decrease (trough) in density in late summer (August/September) and an increase (peak) in April. The decrease in summer density is likely due to surface hoar, a low-density snow crystal formation that is well known to form at Summit Station in the summer when wind speeds are low and humidity relatively high (e.g., Alley et al., 1990; Albert and Schultz, 2002; Dibb and Fahnestock, 2004). As wind speeds increase and water vapor decreases in the winter the surface snow increases in density. The seasonal signal in density is damped out by $1 \mathrm{~m}$ depth at Summit Station. Figure 12 also shows larger natural variability in average density measurements in the top $50 \mathrm{~cm}$ compared to the top $100 \mathrm{~cm}$. This is expected as the deeper snow is more insulated from atmospheric and radiative processes in this dry-snow-zone location.

Figure 13 shows the monthly mean accumulation at Summit Station. Accumulation is highly variable, with slightly lower values in the early summer months (May/June/July). Dibb and Fahnestock (2004) also showed a similar trend in stake measurements and Summit Station from just 2 years of

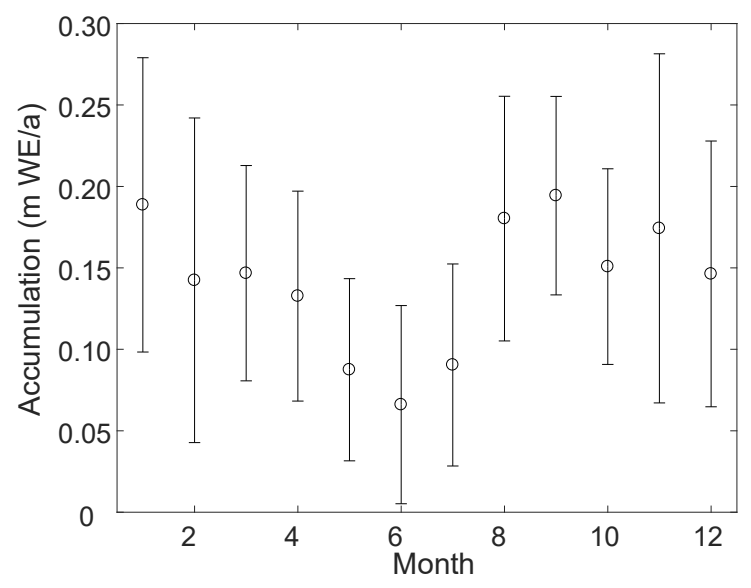

Figure 13. Plot of mean accumulation (circle) and \pm 1 standard deviation (whiskers) for each month at Summit Station, Greenland.

data and explained that the summer season may not actually be seeing a decrease in accumulation, but that thinning layers and densification may be causing the stake measurements to not rise as much in the summertime compared to the wintertime when a snowfall event occurs. Determining whether there is a true decrease in summer accumulation or increase in snow/firn compaction rate at Summit Station requires additional research. 


\section{Data availability}

The SUMup dataset is currently available through the Arctic Data Center. It hosts our three subdatasets in both csv and netcdf formats along with metadata files to further explain the methods and citations. The dataset will be updated annually.

\section{Discussion and conclusion}

We present and describe the SUMup dataset, an expandable, community-based dataset of field measurements of surface mass balance components that is consistent in format, has clearly defined metadata, and is publicly available. The subdatasets include compiled measurements of snow/firn density (https://doi.org/10.18739/A2JH3D23R), accumulation on land ice (https://doi.org/10.18739/A2DR2P790), and snow depth on sea ice (https://doi.org/10.18739/A2WS8HK6X) from the Arctic and Antarctica.

As seen in SUMup, the measurements over the GrIS and AIS are sporadic in time and space, peaking during specific field campaigns and lapsing in between, which makes monitoring change with and understanding processes from field measurements difficult. This is especially prevalent for parameters like density and accumulation that change with both seasonal and climatic atmospheric conditions. Overall, there are gaps in density and accumulation data from $\sim 2000$ forward and from locations on the periphery of the ice sheets. While there currently is a temporal gap in the most recent decades, we note that the GreenTRaCs traverses have collected cores across the GrIS in 2016 and 2017, including at previous PARCA sites. Once these cores are processed, they will be able to help fill some of the time gaps for the GrIS (Robert Hawley, personal communication, 2017).

Density and accumulation measurements of the GrIS oversample cooler, inland regions and undersample coastal, warmer regions. Oversampling these regions may lead to an underestimation of the total average surface density, especially in the summer season, when the measurements are undersampling regions with significant melt processes that increase density. No clear relationship between mean annual temperature and density is seen in the data until a depth of $1 \mathrm{~m}$ where a relationship between higher temperatures and increased density is observed. This suggests that additional parameters, such as wind speed and radiative balance, should be considered when modeling density for the GrIS at SUMup density locations and depths above $1 \mathrm{~m}$. Summit Station, Greenland, is the only location with year-round density and accumulation measurements in the dataset, and on the GrIS, and seasonal cycles are evident in accumulation rate and density for depths above $50 \mathrm{~cm}$.

Our analysis of the SUMup dataset shows gaps in ice sheet measurements in the recent decades and in low-elevation regions on the periphery of the ice sheets. These are the exact regions where climate change will have and has had the largest effects on the Greenland and Antarctic ice sheets (e.g., Shepherd et al., 2012; IMBIE Team, 2018; Enderlin et al., 2014) and where additional future measurements are warranted.

We encourage the cryospheric community to contribute additional field data to the SUMup dataset. We also encourage the cryospheric community, including modelers and scientists working in the field of remote sensing, to use this dataset for model validation for surface mass balance and satellite- or airborne-sensor algorithm development. SUMup is a dynamic, living dataset and is expected to be expanded and released annually.

Author contributions. LM compiled the SUMup dataset into the July 2017 and July 2018 datasets, developed the metadata, and reformatted the dataset. She made all figures for this paper and cowrote the paper. LK co-wrote this paper and developed the first SUMup dataset in 2013. PA helped with the development of the SUMup dataset, performed the initial comparison of the SUMup data to the MAR model, and contributed to the writing of this paper.

Competing interests. The authors declare that they have no conflict of interest.

Acknowledgements. Lynn Montgomery and Lora Koenig acknowledge National Science Foundation grant PLR 1603407 for funding this work. We thank our two anonymous reviewers and our editor, Reinhard Drews, for providing thorough insight and commentary that helped to greatly improve the quality of the manuscript. Publication of this article was funded by the University of Colorado Boulder Libraries Open Access Fund.

Edited by: Reinhard Drews

Reviewed by: two anonymous referees

\section{References}

Albert, M. R.: Snow and Firn Permeability: Characteristics of Snow Megadunes and their Potential Effects on Ice Core Interpretation, U.S. Antarctic Program Data Center (USAPDC), via National Snow and Ice Data Center (NSIDC), https://doi.org/10.7265/N5639MPD, 2007.

Albert, M. R. and Shultz, E. F.: Snow and firn properties and air-snow transport processes at Summit, Greenland, Atmos. Environ., 36, 2789-2797, https://doi.org/10.1016/S13522310(02)00119-X, 2002.

Alley, R. B.: Concerning the Deposition and Diagenesis of Strata in Polar Firn, J. Glaciol., 34, 283-290, https://doi.org/10.3189/S0022143000007024, 1988.

Alley, R. B.: GISP2 Stratigraphy, PANGAEA, https://doi.org/10.1594/PANGAEA.56103, 1999.

Alley, R. B., Saltzman, E. S., Cuffey, K. M., and Fitzpatrick, J. J.: Summertime formation of Depth Hoar in 
central Greenland, Geophys. Res. Lett., 17, 2393-2396, https://doi.org/10.1029/GL017i013p02393, 1990.

Anschütz, H. and Oerter, H.: Accumulation rate of firn core DML67C04_02 (FB0402), PANGAEA, https://doi.org/10.1594/PANGAEA.609883, 2007a.

Anschütz, H. and Oerter, H.: Accumulation rate of firn core DML68C04_03 (FB0403), PANGAEA, https://doi.org/10.1594/PANGAEA.609904, 2007b.

Anschütz, $H$. and Oerter, H.: Accumulation rate of firn core DML71C05_01 (FB0501), PANGAEA, https://doi.org/10.1594/PANGAEA.609905, 2007c.

Anschütz, H. and Oerter, H.: Accumulation rate of firn core DML72C05_02 (FB0502), PANGAEA, https://doi.org/10.1594/PANGAEA.609906, 2007d.

Anschütz, H. and Oerter, H.: Accumulation rate of firn core DML73C05_03 (FB0503), PANGAEA, https://doi.org/10.1594/PANGAEA.609907, 2007e.

Anschütz, H. and Oerter, H.: Accumulation rate of firn core DML74C05_04 (FB0504), PANGAEA, https://doi.org/10.1594/PANGAEA.609908, 2007f.

Arthern, R. J., Winebrenner, D. P., and Vaughan, D. G.: Antarctic snow accumulation mapped using polarization of $4.3-\mathrm{cm}$ wavelength microwave emission, J.. Geophys. Res., 111, D06107, https://doi.org/10.1029/2004JD005667, 2006.

Baker, I.: NEEM Firn Core 2009S2 Density and Permeability, Arctic Data Center, https://doi.org/10.18739/A2Q88G, 2016.

Bales, R. C., McConnell, J. R., Mosley-Thompson, E., and Csatho, B.: Accumulation over the Greenland ice sheet from historical and recent records, J. Geophys. Res., 106, 33813-33825, https://doi.org/10.1029/2001JD900153, 2001.

Banta, J. R., McConnell, J. R., Frey, M. M., Bales, R. C., and Taylor, K.: Spatial and temporal variability in snow accumulation at the West Antarctic Ice Sheet Divide over recent centuries, J. Geophys. Res., 113, D23102, https://doi.org/10.1029/2008JD010235, 2008.

Bellaire, S., Proksch, M., Schneebeli, M., Niwano, M., and Steffen, K.: Measured and Modeled Snow Cover Properties across the Greenland Ice Sheet, The Cryosphere Discuss., https://doi.org/10.5194/tc-2017-55, 2017.

Benson, C.: Greenland Snow Pit and Core Stratigraphy (Analog and Digital Formats), National Snow and Ice Data Center, Boulder, Colorado USA, 2013.

Benson, C. S.: Greenland Snow it and Core Stratigraphy, Carl S. Benson Collection, Coll. 2010011, Roger G. Barry Archives and Resource Center, National Snow Data Center, Colorado USA, 2017.

Bolzan, J. F. and Strobel, M.: Oxygen isotope data from snowpit at GISP2 Site 13, PANGAEA, https://doi.org/10.1594/PANGAEA.55510, 1999a.

Bolzan, J. F. and Strobel, M.: Oxygen isotope data from snowpit at GISP2 Site 15, PANGAEA, https://doi.org/10.1594/PANGAEA.55511, 1999b.

Bolzan, J. F. and Strobel, M.: Oxygen isotope data from snowpit at GISP2 Site 31, PANGAEA, https://doi.org/10.1594/PANGAEA.55512, 1999c.

Bolzan, J. F. and Strobel, M.: Oxygen isotope data from snowpit at GISP2 Site 37, PANGAEA, https://doi.org/10.1594/PANGAEA.55513, 1999d.
Bolzan, J. F. and Strobel, M.: Oxygen isotope data from snowpit at GISP2 Site 51, PANGAEA, https://doi.org/10.1594/PANGAEA.55514, 1999e.

Bolzan, J. F. and Strobel, M.: Oxygen isotope data from snowpit at GISP2 Site 57, PANGAEA, https://doi.org/10.1594/PANGAEA.55515, 1999 f.

Bolzan, J. F. and Strobel, M.: Oxygen isotope data from snowpit at GISP2 Site 73, PANGAEA, https://doi.org/10.1594/PANGAEA.55516, 1999g.

Bolzan, J. F. and Strobel, M.: Oxygen isotope data from snowpit at GISP2 Site 44, PANGAEA, https://doi.org/10.1594/PANGAEA.59995, 2001a.

Bolzan, J. F. and Strobel, M.: Oxygen isotope data from snowpit at GISP2 Site 571, PANGAEA, https://doi.org/10.1594/PANGAEA.59996, 2001b.

Burgener, L., Rupper, S., Koenig, L., Forster, R., Christensen, W. F., Williams, J., Koutnik, M., Miège, C., Steig, E. J., Tingey, D., Keeler, D., and Riley, L.: An observed negative trend in West Antarctic accumulation rates from 1975 to 2010: Evidence from new observed and simulated records, J. Geophys. Res.-Atmos., 118, 4205-4216, https://doi.org/10.1002/jgrd.50362, 2013.

Burgess, E. W., Forster, R. R., Box, J. E., Mosley-Thompson, E., Bromwich, D. H., Bales, R. C., and Smith, L. C.: A spatially calibrated model of annual accumulation rate on the Greenland Ice Sheet (1958-2007), J. Geophys. Res., 115, F02004, https://doi.org/10.1029/2009JF001293, 2010.

Chellman, N.: Core Atmospheric and Snow Measurements at Summit Greenland Environmental Observatory: Snow Pit, Arctic Data Center, https://doi.org/10.18739/A2888F, 2016.

Conger, S. M. and McClung, D. M.: Comparison of density cutters for snow profile observations, J. Glaciol., 55, 163-169, https://doi.org/10.3189/002214309788609038, 2009.

Conway, H.: Roosevelt Island Ice Core Density and Beta Count Data, U.S. Antarctic Program Data Center, https://doi.org/10.7265/N55718ZW, 2003.

Cooper, M. G., Smith, L. C., Rennermalm, A. K., Pitcher, L., Ryan, J. C., Yang, K., and Cooley, S. W.: Direct measurements of ice density down to $1 \mathrm{~m}$ depth in the Greenland Ice Sheet ablation zone during July 2016 from shallow ice cores, In supplement to: Cooper, MG et al. (accepted): Near surface meltwater storage in low-density bare ice of the Greenland ice sheet ablation zone. The Cryosphere Discussions, 1-25, https://doi.org/10.5194/tc2017-107, https://doi.org/10.1594/PANGAEA.886747, 2018.

Courville, Z. R., Albert, M. R., Fahnestock, M. A., Cathles, L. M., and Shuman, C. A.: Impacts of an accumulation hiatus on the physical properties of firn at a lowaccumulation polar site, J. Geophys. Res., 112, F02030, https://doi.org/10.1029/2005JF000429, 2007.

Dibb, J. E. and Fahnestock, M.: Snow accumulation, surface height change, and firn densification at Summit, Greenland: Insights from 2 years of in situ observation, J. Geophys. Res., 109, D24113, https://doi.org/10.1029/2003JD004300, 2004.

Dibb, J. E., Whitlow, S. I., and Arsenault, M.: Seasonal variations in the soluble ion content of snow at Summit. Greenland: Constraints from three years of daily surface snow samples, Atmos. Environ., 41, 5007-5019, https://doi.org/10.1016/j.atmosenv.2006.12.010, 2007.

Enderlin, E. M., Howat, I. M., Jeong, S., Noh, M.-J., van Angelen, J. H., and van den Broeke, M. R.: An improved mass budget 
for the Greenland ice sheet, Geophys. Res. Lett., 41, 866-872, https://doi.org/10.1002/2013GL059010, 2014.

Fausto, R. S., Box, J. E., Vandecrux, B., van As, D., Steffen, K., MacFerrin, M. J., Machguth, H., Colgan, W., Koenig, L. S., McGrath, D., Charalampidis, C., and Braithwaite, R. J.: A Snow Density Dataset for Improving Surface Boundary Conditions in Greenland Ice Sheet Firn Modeling, Front. Earth Sci., 6, 51, https://doi.org/10.3389/feart.2018.00051, 2018.

Favier, V., Agosta, C., Parouty, S., Durand, G., Delaygue, G., Gallée, H., Drouet, A.-S., Trouvilliez, A., and Krinner, G.: An updated and quality controlled surface mass balance dataset for Antarctica, The Cryosphere, 7, 583-597, https://doi.org/10.5194/tc-7-583-2013, 2013.

Fernandoy, F., Meyer, H., Oerter, H., Wilhelms, F., Graf, W. and Schwander, J.: Annual means of $\mathrm{d} 18 \mathrm{O}$, density, and accumulation rates of firn core DML641C02_01, In supplement to: Fernandoy, F et al. (2010): Temporal and Spatial variation of stable-isotope ratios and accumulation rates in the hinterland of Neumayer station, East Antarctica, J. Glaciol., 56, 673-687, https://doi.org/10.3189/002214310793146296, https://doi.org/10.1594/PANGAEA.753157, 2010a.

Fernandoy, F., Meyer, H., Oerter, H., Wilhelms, F., Graf, W., and Schwander, J.: Annual means of d180, density, and accumulation rates of firn core DML651C02_03, In supplement to: Fernandoy, F et al. (2010): Temporal and Spatial variation of stable-isotope ratios and accumulation rates in the hinterland of Neumayer station, East Antarctica, J. Glaciol., 56, 673-687, https://doi.org/10.3189/002214310793146296, https://doi.org/10.1594/PANGAEA.753158, 2010b.

Fernandoy, F., Meyer, H., Oerter, H., Wilhelms, F., Graf, W., and Schwander, J.: Annual means of d180, deuterium, density, and accumulation rates of firn core NM02C02_02, In supplement to: Fernandoy, F et al. (2010): Temporal and Spatial variation of stable-isotope ratios and accumulation rates in the hinterland of Neumayer station, East Antarctica, J. Glaciol., 56, 673-687, https://doi.org/10.3189/002214310793146296, https://doi.org/10.1594/PANGAEA.753159, 2010c.

Ferris, D. G., Cole-Dai, J., Reyes, A. R., and Budner, D. M.: South Pole ice core record of explosive volcanic eruptions in the first and second millennia A.D. and evidence of a large eruption in the tropics around 535 A.D., J. Geophys. Res., 116, D17308, https://doi.org/10.1029/2011JD015916, 2011.

Fettweis, X., Franco, B., Tedesco, M., van Angelen, J. H., Lenaerts, J. T. M., van den Broeke, M. R., and Gallée, H.: Estimating the Greenland ice sheet surface mass balance contribution to future sea level rise using the regional atmospheric climate model MAR, The Cryosphere, 7, 469-489, https://doi.org/10.5194/tc7-469-2013, 2013.

Fettweis, X., Box, J. E., Agosta, C., Amory, C., Kittel, C., Lang, C., van As, D., Machguth, H., and Gallée, H.: Reconstructions of the 1900-2015 Greenland ice sheet surface mass balance using the regional climate MAR model, The Cryosphere, 11, 1015-1033, https://doi.org/10.5194/tc-11-1015-2017, 2017.

Gardner, J., Richter-Menge, J., Farrell, S., and Brozena, J.: Coincident multiscale estimates of Arctic sea ice thickness, Eos T. Am. Geophys. Un., 93, 57-58, https://doi.org/10.1029/2012EO060001, 2012.

Gerland, S. and Wilhelms, F.: Continuous density log of icecore BER11C95_25, Supplement to: Gerland, Sebastian; Oerter,
Hans; Kipfstuhl, Sepp; Wilhelms, Frank; Miller, Heinz (1999): Continuous density $\log$ of a 181 metre long ice core from the summit of Berkner Island, Antarctica, Ann. Glaciol., 29, 215-219, https://doi.org/10.3189/172756499781821427, https://doi.org/10.1594/PANGAEA.227732, 1999.

Graf, W. and Oerter, H.: Annual means of density, d180, and accumulation rates of snow pit BER01S90_01, In supplement to: Graf, Wolfgang; Moser, Heribert; Reinwarth, Oskar; Kipfstuhl, Sepp; Oerter, Hans; Minikin, Andreas; Wagenbach, Dietmar (1994): Snow-accumulation rates and isotopic content $(2 \mathrm{H}, 3 \mathrm{H})$ of near-surface firn from the Filchner-Ronne Ice Shelf, Antarctica, Ann. Glaciol., 20, 121-128, hdl:10013/epic.11645.d001, https://doi.org/10.1594/PANGAEA.548700, 2006a.

Graf, W. and Oerter, H.: Annual means of density, d180, and accumulation rates of snow pit BER01S90_01, In supplement to: Graf, Wolfgang; Moser, Heribert; Reinwarth, Oskar; Kipfstuhl, Sepp; Oerter, Hans; Minikin, Andreas; Wagenbach, Dietmar (1994): Snow-accumulation rates and isotopic content $(2 \mathrm{H}, 3 \mathrm{H})$ of near-surface firn from the Filchner-Ronne Ice Shelf, Antarctica, Ann. Glaciol., 20, 121-128, hdl:10013/epic.11645.d001, https://doi.org/10.1594/PANGAEA.548700, 2006b.

Graf, W. and Oerter, H.: Annual means of density, d18O, and accumulation rates of snow pit BER02S90_02, In supplement to: Graf, Wolfgang; Moser, Heribert; Reinwarth, Oskar; Kipfstuhl, Sepp; Oerter, Hans; Minikin, Andreas; Wagenbach, Dietmar (1994): Snow-accumulation rates and isotopic content $(2 \mathrm{H}, 3 \mathrm{H})$ of near-surface firn from the Filchner-Ronne Ice Shelf, Antarctica, Ann. Glaciol., 20, 121-128, hdl:10013/epic.11645.d001, https://doi.org/10.1594/PANGAEA.548701, 2006c.

Graf, W. and Oerter, H.: Annual means of density, d18O, and accumulation rates of snow pit BER02S90_02, In supplement to: Graf, Wolfgang; Moser, Heribert; Reinwarth, Oskar; Kipfstuhl, Sepp; Oerter, Hans; Minikin, Andreas; Wagenbach, Dietmar (1994): Snow-accumulation rates and isotopic content $(2 \mathrm{H}, 3 \mathrm{H})$ of near-surface firn from the Filchner-Ronne Ice Shelf, Antarctica, Ann. Glaciol., 20, 121-128, hdl:10013/epic.11645.d001, https://doi.org/10.1594/PANGAEA.548701, 2006d.

Graf, W. and Oerter, H.: Annual means of density, d18O, and accumulation rates of snow pit FRI11S90_235, In supplement to: Graf, Wolfgang; Moser, Heribert; Reinwarth, Oskar; Kipfstuhl, Sepp; Oerter, Hans; Minikin, Andreas; Wagenbach, Dietmar (1994): Snow-accumulation rates and isotopic content $(2 \mathrm{H}, 3 \mathrm{H})$ of near-surface firn from the Filchner-Ronne Ice Shelf, Antarctica, Ann. Glaciol., 20, 121-128, hdl:10013/epic.11645.d001, https://doi.org/10.1594/PANGAEA.548664, 2006e.

Graf, W. and Oerter, H.: Annual means of density, d18O, and accumulation rates of snow pit FRI12S90_236, In supplement to: Graf, Wolfgang; Moser, Heribert; Reinwarth, Oskar; Kipfstuhl, Sepp; Oerter, Hans; Minikin, Andreas; Wagenbach, Dietmar (1994): Snow-accumulation rates and isotopic content $(2 \mathrm{H}, 3 \mathrm{H})$ of near-surface firn from the Filchner-Ronne Ice Shelf, Antarctica, Ann. Glaciol., 20, 121-128, hdl:10013/epic.11645.d001, https://doi.org/10.1594/PANGAEA.548665, 2006 f.

Graf, W. and Oerter, H.: Annual means of density, d180, and accumulation rates of snow pit FRI12S90_236, In supplement to: Graf, Wolfgang; Moser, Heribert; Reinwarth, Oskar; Kipfstuhl, Sepp; Oerter, Hans; Minikin, Andreas; Wagenbach, Dietmar (1994): Snow-accumulation rates and isotopic content $(2 \mathrm{H}, 3 \mathrm{H})$ of near-surface firn from the Filchner-Ronne Ice Shelf, Antarc- 
tica, Ann. Glaciol., 20, 121-128, hdl:10013/epic.11645.d001, https://doi.org/10.1594/PANGAEA.548665, 2006g.

Graf, W. and Oerter, H.: Annual means of density, d180, and accumulation rates of snow pit FRI13S90_335, In supplement to: Graf, Wolfgang; Moser, Heribert; Reinwarth, Oskar; Kipfstuhl, Sepp; Oerter, Hans; Minikin, Andreas; Wagenbach, Dietmar (1994): Snow-accumulation rates and isotopic content $(2 \mathrm{H}, 3 \mathrm{H})$ of near-surface firn from the Filchner-Ronne Ice Shelf, Antarctica, Ann. Glaciol., 20, 121-128, hdl:10013/epic.11645.d001, https://doi.org/10.1594/PANGAEA.548666, 2006h.

Graf, W. and Oerter, H.: Annual means of density, d18O, and accumulation rates of snow pit FRI15S90_131, In supplement to: Graf, Wolfgang; Moser, Heribert; Reinwarth, Oskar; Kipfstuhl, Sepp; Oerter, Hans; Minikin, Andreas; Wagenbach, Dietmar (1994): Snow-accumulation rates and isotopic content $(2 \mathrm{H}, 3 \mathrm{H})$ of near-surface firn from the Filchner-Ronne Ice Shelf, Antarctica, Ann. Glaciol., 20, 121-128, hdl:10013/epic.11645.d001, https://doi.org/10.1594/PANGAEA.548667, $2006 \mathrm{i}$.

Graf, W. and Oerter, H.: Annual means of density, d18O, and accumulation rates of snow pit FRI16S90_230, In supplement to: Graf, Wolfgang; Moser, Heribert; Reinwarth, Oskar; Kipfstuhl, Sepp; Oerter, Hans; Minikin, Andreas; Wagenbach, Dietmar (1994): Snow-accumulation rates and isotopic content $(2 \mathrm{H}, 3 \mathrm{H})$ of near-surface firn from the Filchner-Ronne Ice Shelf, Antarctica, Ann. Glaciol., 20, 121-128, hdl:10013/epic.11645.d001, https://doi.org/10.1594/PANGAEA.548668, 2006j.

Graf, W. and Oerter, H.: Annual means of density, d180, and accumulation rates of snow pit FRI17S90_231, In supplement to: Graf, Wolfgang; Moser, Heribert; Reinwarth, Oskar; Kipfstuhl, Sepp; Oerter, Hans; Minikin, Andreas; Wagenbach, Dietmar (1994): Snow-accumulation rates and isotopic content $(2 \mathrm{H}, 3 \mathrm{H})$ of near-surface firn from the Filchner-Ronne Ice Shelf, Antarctica, Ann. Glaciol., 20, 121-128, hdl:10013/epic.11645.d001, https://doi.org/10.1594/PANGAEA.548669, 2006k.

Graf, W. and Oerter, H.: Annual means of density, d180, deuterium, and accumulation rates of firn core FRI21C90_HWF, In supplement to: Graf, Wolfgang; Moser, Heribert; Reinwarth, Oskar; Kipfstuhl, Sepp; Oerter, Hans; Minikin, Andreas; Wagenbach, Dietmar (1994): Snow-accumulation rates and isotopic content $(2 \mathrm{H}, 3 \mathrm{H})$ of near-surface firn from the Filchner-Ronne Ice Shelf, Antarctica, Ann. Glaciol., 20, 121-128, hdl:10013/epic.11645.d001, https://doi.org/10.1594/PANGAEA.548652, 20061.

Graf, W. and Oerter, H.: Annual means of density, d180, deuterium, and accumulation rates of snow pit FRI18S90_330, In supplement to: Graf, Wolfgang; Moser, Heribert; Reinwarth, Oskar; Kipfstuhl, Sepp; Oerter, Hans; Minikin, Andreas; Wagenbach, Dietmar (1994): Snow-accumulation rates and isotopic content $(2 \mathrm{H}, 3 \mathrm{H})$ of near-surface firn from the Filchner-Ronne Ice Shelf, Antarctica, Ann. Glaciol., 20, 121-128, hdl:10013/epic.11645.d001, https://doi.org/10.1594/PANGAEA.548670, 2006m.

Graf, W. and Oerter, H.: Annual means of density, d18O, deuterium, tritium, and accumulation rates of firn core FRI10C90_136, In supplement to: Graf, Wolfgang; Moser, Heribert; Reinwarth, Oskar; Kipfstuhl, Sepp; Oerter, Hans; Minikin, Andreas; Wagenbach, Dietmar (1994): Snowaccumulation rates and isotopic content $(2 \mathrm{H}, 3 \mathrm{H})$ of nearsurface firn from the Filchner-Ronne Ice Shelf, Antarctica,
Ann. Glaciol., 20, 121-128, hdl:10013/epic.11645.d001, https://doi.org/10.1594/PANGAEA.548641, 2006n.

Graf, W. and Oerter, H.: Annual means of density, d18O, deuterium, tritium, and accumulation rates of firn core FRI12C90_236, In supplement to: Graf, Wolfgang; Moser, Heribert; Reinwarth, Oskar; Kipfstuhl, Sepp; Oerter, Hans; Minikin, Andreas; Wagenbach, Dietmar (1994): Snowaccumulation rates and isotopic content $(2 \mathrm{H}, 3 \mathrm{H})$ of nearsurface firn from the Filchner-Ronne Ice Shelf, Antarctica, Ann. Glaciol., 20, 121-128, hdl:10013/epic.11645.d001, https://doi.org/10.1594/PANGAEA.548643, 2006 o.

Graf, W. and Oerter, H.: Annual means of density, d18O, deuterium, tritium, and accumulation rates of firn core FRI14C90_336, In supplement to: Graf, Wolfgang; Moser, Heribert; Reinwarth, Oskar; Kipfstuhl, Sepp; Oerter, Hans; Minikin, Andreas; Wagenbach, Dietmar (1994): Snowaccumulation rates and isotopic content $(2 \mathrm{H}, 3 \mathrm{H})$ of nearsurface firn from the Filchner-Ronne Ice Shelf, Antarctica, Ann. Glaciol., 20, 121-128, hdl:10013/epic.11645.d001, https://doi.org/10.1594/PANGAEA.548645, 2006p.

Graf, W. and Oerter, H.: Annual means of density, d18O, deuterium, tritium, and accumulation rates of firn core FRI16C90_230, In supplement to: Graf, Wolfgang; Moser, Heribert; Reinwarth, Oskar; Kipfstuhl, Sepp; Oerter, Hans; Minikin, Andreas; Wagenbach, Dietmar (1994): Snowaccumulation rates and isotopic content $(2 \mathrm{H}, 3 \mathrm{H})$ of nearsurface firn from the Filchner-Ronne Ice Shelf, Antarctica, Ann. Glaciol., 20, 121-128, hdl:10013/epic.11645.d001, https://doi.org/10.1594/PANGAEA.548647, 2006q.

Graf, W. and Oerter, H.: Annual means of density, d18O, deuterium, tritium, and accumulation rates of firn core FRI18C90_330, In supplement to: Graf, Wolfgang; Moser, Heribert; Reinwarth, Oskar; Kipfstuhl, Sepp; Oerter, Hans; Minikin, Andreas; Wagenbach, Dietmar (1994): Snowaccumulation rates and isotopic content $(2 \mathrm{H}, 3 \mathrm{H})$ of nearsurface firn from the Filchner-Ronne Ice Shelf, Antarctica, Ann. Glaciol., 20, 121-128, hdl:10013/epic.11645.d001, https://doi.org/10.1594/PANGAEA.548649, 2006r.

Graf, W. and Oerter, H.: Annual means of density, d18O, deuterium, tritium, and accumulation rates of firn core FRI19C90_05, In supplement to: Graf, Wolfgang; Moser, Heribert; Reinwarth, Oskar; Kipfstuhl, Sepp; Oerter, Hans; Minikin, Andreas; Wagenbach, Dietmar (1994): Snowaccumulation rates and isotopic content $(2 \mathrm{H}, 3 \mathrm{H})$ of nearsurface firn from the Filchner-Ronne Ice Shelf, Antarctica, Ann. Glaciol., 20, 121-128, hdl:10013/epic.11645.d001, https://doi.org/10.1594/PANGAEA.548650, 2006s.

Graf, W. and Oerter, H.: Annual means of density, d180, deuterium, tritium, and accumulation rates of firn core FRI20C90_06, In supplement to: Graf, Wolfgang; Moser, Heribert; Reinwarth, Oskar; Kipfstuhl, Sepp; Oerter, Hans; Minikin, Andreas; Wagenbach, Dietmar (1994): Snowaccumulation rates and isotopic content $(2 \mathrm{H}, 3 \mathrm{H})$ of nearsurface firn from the Filchner-Ronne Ice Shelf, Antarctica, Ann. Glaciol., 20, 121-128, hdl:10013/epic.11645.d001, https://doi.org/10.1594/PANGAEA.548651, 2006t.

Graf, W. and Oerter, H.: Annual means of density, deuterium, and accumulation rates of firn core FRI09C90_90, In supplement to: Graf, Wolfgang; Moser, Heribert; Reinwarth, Oskar; Kipfs- 
tuhl, Sepp; Oerter, Hans; Minikin, Andreas; Wagenbach, Dietmar (1994): Snow-accumulation rates and isotopic content $(2 \mathrm{H}, 3 \mathrm{H})$ of near-surface firn from the Filchner-Ronne Ice Shelf, Antarctica, Ann. Glaciol., 20, 121-128, hdl:10013/epic.11645.d001, https://doi.org/10.1594/PANGAEA.548640, 2006u.

Graf, W. and Oerter, H.: Annual means of density, deuterium, and accumulation rates of firn core FRI11C90_235, In supplement to: Graf, Wolfgang; Moser, Heribert; Reinwarth, Oskar; Kipfstuhl, Sepp; Oerter, Hans; Minikin, Andreas; Wagenbach, Dietmar (1994): Snow-accumulation rates and isotopic content $(2 \mathrm{H}, 3 \mathrm{H})$ of near-surface firn from the Filchner-Ronne Ice Shelf, Antarctica, Ann. Glaciol., 20, 121-128, hdl:10013/epic.11645.d001, https://doi.org/10.1594/PANGAEA.548642, 2006v.

Graf, W. and Oerter, H.: Annual means of density, deuterium, and accumulation rates of firn core FRI13C90_335, In supplement to: Graf, Wolfgang; Moser, Heribert; Reinwarth, Oskar; Kipfstuhl, Sepp; Oerter, Hans; Minikin, Andreas; Wagenbach, Dietmar (1994): Snow-accumulation rates and isotopic content $(2 \mathrm{H}, 3 \mathrm{H})$ of near-surface firn from the Filchner-Ronne Ice Shelf, Antarctica, Ann. Glaciol., 20, 121-128, hdl:10013/epic.11645.d001, https://doi.org/10.1594/PANGAEA.548644, 2006w.

Graf, W. and Oerter, H.: Annual means of density, deuterium, and accumulation rates of firn core FRI15C90_131, In supplement to: Graf, Wolfgang; Moser, Heribert; Reinwarth, Oskar; Kipfstuhl, Sepp; Oerter, Hans; Minikin, Andreas; Wagenbach, Dietmar (1994): Snow-accumulation rates and isotopic content $(2 \mathrm{H}, 3 \mathrm{H})$ of near-surface firn from the Filchner-Ronne Ice Shelf, Antarctica, Ann. Glaciol., 20, 121-128, hdl:10013/epic.11645.d001, https://doi.org/10.1594/PANGAEA.548646, 2006x.

Graf, W. and Oerter, H.: Annual means of density, deuterium, and accumulation rates of firn core FRI17C90_231, In supplement to: Graf, Wolfgang; Moser, Heribert; Reinwarth, Oskar; Kipfstuhl, Sepp; Oerter, Hans; Minikin, Andreas; Wagenbach, Dietmar (1994): Snow-accumulation rates and isotopic content $(2 \mathrm{H}, 3 \mathrm{H})$ of near-surface firn from the Filchner-Ronne Ice Shelf, Antarctica, Ann. Glaciol., 20, 121-128, hdl:10013/epic.11645.d001, https://doi.org/10.1594/PANGAEA.548648, 2006y.

Graf, W. and Oerter, H.: Density and d180 of firn core FRI02C92_246, In supplement to: Graf, Wolfgang; Moser, Heribert; Reinwarth, Oskar; Kipfstuhl, Sepp; Oerter, Hans; Minikin, Andreas; Wagenbach, Dietmar (1994): Snowaccumulation rates and isotopic content $(2 \mathrm{H}, 3 \mathrm{H})$ of nearsurface firn from the Filchner-Ronne Ice Shelf, Antarctica, Ann. Glaciol., 20, 121-128, hdl:10013/epic.11645.d001, https://doi.org/10.1594/PANGAEA.548623, $2006 \mathrm{z}$.

Graf, W. and Oerter, H.: Density and d18O of snow pit FRI10S90_136, In supplement to: Graf, Wolfgang; Moser, Heribert; Reinwarth, Oskar; Kipfstuhl, Sepp; Oerter, Hans; Minikin, Andreas; Wagenbach, Dietmar (1994): Snowaccumulation rates and isotopic content $(2 \mathrm{H}, 3 \mathrm{H})$ of nearsurface firn from the Filchner-Ronne Ice Shelf, Antarctica, Ann. Glaciol., 20, 121-128, hdl:10013/epic.11645.d001, https://doi.org/10.1594/PANGAEA.548655, 2006 aa.

Graf, W. and Oerter, H.: Density and d18O of snow pit FRI11S90_235, In supplement to: Graf, Wolfgang; Moser, Heribert; Reinwarth, Oskar; Kipfstuhl, Sepp; Oerter, Hans; Minikin, Andreas; Wagenbach, Dietmar (1994): Snowaccumulation rates and isotopic content $(2 \mathrm{H}, 3 \mathrm{H})$ of nearsurface firn from the Filchner-Ronne Ice Shelf, Antarctica,
Ann. Glaciol., 20, 121-128, hdl:10013/epic.11645.d001, https://doi.org/10.1594/PANGAEA.548656, 2006ab.

Graf, W. and Oerter, H.: Density and d18O of snow pit FRI12S90_236, In supplement to: Graf, Wolfgang; Moser, Heribert; Reinwarth, Oskar; Kipfstuhl, Sepp; Oerter, Hans; Minikin, Andreas; Wagenbach, Dietmar (1994): Snowaccumulation rates and isotopic content $(2 \mathrm{H}, 3 \mathrm{H})$ of nearsurface firn from the Filchner-Ronne Ice Shelf, Antarctica, Ann. Glaciol., 20, 121-128, hdl:10013/epic.11645.d001, https://doi.org/10.1594/PANGAEA.548657, 2006ac. Graf, W. and Oerter, H.: Density and d18O of snow pit FRI13S90_335, In supplement to: Graf, Wolfgang; Moser, Heribert; Reinwarth, Oskar; Kipfstuhl, Sepp; Oerter, Hans; Minikin, Andreas; Wagenbach, Dietmar (1994): Snowaccumulation rates and isotopic content $(2 \mathrm{H}, 3 \mathrm{H})$ of nearsurface firn from the Filchner-Ronne Ice Shelf, Antarctica, Ann. Glaciol., 20, 121-128, hdl:10013/epic.11645.d001, https://doi.org/10.1594/PANGAEA.548658, 2006ad.

Graf, W. and Oerter, H.: Density and d180 of snow pit FRI15S90_131, In supplement to: Graf, Wolfgang; Moser, Heribert; Reinwarth, Oskar; Kipfstuhl, Sepp; Oerter, Hans; Minikin, Andreas; Wagenbach, Dietmar (1994): Snowaccumulation rates and isotopic content $(2 \mathrm{H}, 3 \mathrm{H})$ of nearsurface firn from the Filchner-Ronne Ice Shelf, Antarctica, Ann. Glaciol., 20, 121-128, hdl:10013/epic.11645.d001, https://doi.org/10.1594/PANGAEA.548659, 2006ae.

Graf, W. and Oerter, H.: Density and d180 of snow pit FRI16S90_230, In supplement to: Graf, Wolfgang; Moser, Heribert; Reinwarth, Oskar; Kipfstuhl, Sepp; Oerter, Hans; Minikin, Andreas; Wagenbach, Dietmar (1994): Snowaccumulation rates and isotopic content $(2 \mathrm{H}, 3 \mathrm{H})$ of nearsurface firn from the Filchner-Ronne Ice Shelf, Antarctica, Ann. Glaciol., 20, 121-128, hdl:10013/epic.11645.d001, https://doi.org/10.1594/PANGAEA.548660, 2006af.

Graf, W. and Oerter, H.: Density and $\mathrm{d} 18 \mathrm{O}$ of snow pit FRI17S90_231, In supplement to: Graf, Wolfgang; Moser, Heribert; Reinwarth, Oskar; Kipfstuhl, Sepp; Oerter, Hans; Minikin, Andreas; Wagenbach, Dietmar (1994): Snowaccumulation rates and isotopic content $(2 \mathrm{H}, 3 \mathrm{H})$ of nearsurface firn from the Filchner-Ronne Ice Shelf, Antarctica, Ann. Glaciol., 20, 121-128, hdl:10013/epic.11645.d001, https://doi.org/10.1594/PANGAEA.548661, 2006ag.

Graf, W. and Oerter, H.: Density and deuterium of firn core FRI09C90_90, In supplement to: Graf, Wolfgang; Moser, Heribert; Reinwarth, Oskar; Kipfstuhl, Sepp; Oerter, Hans; Minikin, Andreas; Wagenbach, Dietmar (1994): Snowaccumulation rates and isotopic content $(2 \mathrm{H}, 3 \mathrm{H})$ of nearsurface firn from the Filchner-Ronne Ice Shelf, Antarctica, Ann. Glaciol., 20, 121-128, hdl:10013/epic.11645.d001, https://doi.org/10.1594/PANGAEA.548624, 2006ah.

Graf, W. and Oerter, H.: Density and deuterium of firn core FRI11C90_235, In supplement to: Graf, Wolfgang; Moser, Heribert; Reinwarth, Oskar; Kipfstuhl, Sepp; Oerter, Hans; Minikin, Andreas; Wagenbach, Dietmar (1994): Snowaccumulation rates and isotopic content $(2 \mathrm{H}, 3 \mathrm{H})$ of nearsurface firn from the Filchner-Ronne Ice Shelf, Antarctica, Ann. Glaciol., 20, 121-128, hdl:10013/epic.11645.d001, https://doi.org/10.1594/PANGAEA.548626, 2006ai. 
Graf, W. and Oerter, H.: Density and deuterium of firn core FRI13C90_335, In supplement to: Graf, Wolfgang; Moser, Heribert; Reinwarth, Oskar; Kipfstuhl, Sepp; Oerter, Hans; Minikin, Andreas; Wagenbach, Dietmar (1994): Snowaccumulation rates and isotopic content $(2 \mathrm{H}, 3 \mathrm{H})$ of nearsurface firn from the Filchner-Ronne Ice Shelf, Antarctica, Ann. Glaciol., 20, 121-128, hdl:10013/epic.11645.d001, https://doi.org/10.1594/PANGAEA.548628, 2006aj.

Graf, W. and Oerter, H.: Density and deuterium of firn core FRI15C90_131, In supplement to: Graf, Wolfgang; Moser, Heribert; Reinwarth, Oskar; Kipfstuhl, Sepp; Oerter, Hans; Minikin, Andreas; Wagenbach, Dietmar (1994): Snowaccumulation rates and isotopic content $(2 \mathrm{H}, 3 \mathrm{H})$ of nearsurface firn from the Filchner-Ronne Ice Shelf, Antarctica, Ann. Glaciol., 20, 121-128, hdl:10013/epic.11645.d001, https://doi.org/10.1594/PANGAEA.548630, 2006ak.

Graf, W. and Oerter, H.: Density and deuterium of firn core FRI17C90_231, In supplement to: Graf, Wolfgang; Moser, Heribert; Reinwarth, Oskar; Kipfstuhl, Sepp; Oerter, Hans; Minikin, Andreas; Wagenbach, Dietmar (1994): Snowaccumulation rates and isotopic content $(2 \mathrm{H}, 3 \mathrm{H})$ of nearsurface firn from the Filchner-Ronne Ice Shelf, Antarctica, Ann. Glaciol., 20, 121-128, hdl:10013/epic.11645.d001, https://doi.org/10.1594/PANGAEA.548632, 2006al.

Graf, W. and Oerter, H.: Density, d18O, and deuterium of firn core FRI21C90_HWF, In supplement to: Graf, Wolfgang; Moser, Heribert; Reinwarth, Oskar; Kipfstuhl, Sepp; Oerter, Hans; Minikin, Andreas; Wagenbach, Dietmar (1994): Snow-accumulation rates and isotopic content $(2 \mathrm{H}, 3 \mathrm{H})$ of near-surface firn from the Filchner-Ronne Ice Shelf, Antarctica, Ann. Glaciol., 20, 121-128, hdl:10013/epic.11645.d001, https://doi.org/10.1594/PANGAEA.548636, 2006am.

Graf, W. and Oerter, H.: Density, $\mathrm{d} 18 \mathrm{O}$ and deuterium of snow pit FRI18S90_330, In supplement to: Graf, Wolfgang; Moser, Heribert; Reinwarth, Oskar; Kipfstuhl, Sepp; Oerter, Hans; Minikin, Andreas; Wagenbach, Dietmar (1994): Snowaccumulation rates and isotopic content $(2 \mathrm{H}, 3 \mathrm{H})$ of nearsurface firn from the Filchner-Ronne Ice Shelf, Antarctica, Ann. Glaciol., 20, 121-128, hdl:10013/epic.11645.d001, https://doi.org/10.1594/PANGAEA.548662, 2006an.

Graf, W. and Oerter, H.: Density, d180, deuterium, and tritium of firn core FRI10C90_136, In supplement to: Graf, Wolfgang; Moser, Heribert; Reinwarth, Oskar; Kipfstuhl, Sepp; Oerter, Hans; Minikin, Andreas; Wagenbach, Dietmar (1994): Snow-accumulation rates and isotopic content $(2 \mathrm{H}, 3 \mathrm{H})$ of near-surface firn from the Filchner-Ronne Ice Shelf, Antarctica, Ann. Glaciol., 20, 121-128, hdl:10013/epic.11645.d001, https://doi.org/10.1594/PANGAEA.548625, 2006ao.

Graf, W. and Oerter, H.: Density, d180, deuterium, and tritium of firn core FRI12C90_236, In supplement to: Graf, Wolfgang; Moser, Heribert; Reinwarth, Oskar; Kipfstuhl, Sepp; Oerter, Hans; Minikin, Andreas; Wagenbach, Dietmar (1994): Snow-accumulation rates and isotopic content $(2 \mathrm{H}, 3 \mathrm{H})$ of near-surface firn from the Filchner-Ronne Ice Shelf, Antarctica, Ann. Glaciol., 20, 121-128, hdl:10013/epic.11645.d001, https://doi.org/10.1594/PANGAEA.548627, 2006ap.

Graf, W. and Oerter, H.: Density, d180, deuterium, and tritium of firn core FRI14C90_336, In supplement to: Graf, Wolfgang; Moser, Heribert; Reinwarth, Oskar; Kipfstuhl, Sepp;
Oerter, Hans; Minikin, Andreas; Wagenbach, Dietmar (1994): Snow-accumulation rates and isotopic content $(2 \mathrm{H}, 3 \mathrm{H})$ of near-surface firn from the Filchner-Ronne Ice Shelf, Antarctica, Ann. Glaciol., 20, 121-128, hdl:10013/epic.11645.d001, https://doi.org/10.1594/PANGAEA.548629, 2006aq.

Graf, W. and Oerter, H.: Density, d18O, deuterium, and tritium of firn core FRI16C90_230, In supplement to: Graf, Wolfgang; Moser, Heribert; Reinwarth, Oskar; Kipfstuhl, Sepp; Oerter, Hans; Minikin, Andreas; Wagenbach, Dietmar (1994): Snow-accumulation rates and isotopic content $(2 \mathrm{H}, 3 \mathrm{H})$ of near-surface firn from the Filchner-Ronne Ice Shelf, Antarctica, Ann. Glaciol., 20, 121-128, hdl:10013/epic.11645.d001, https://doi.org/10.1594/PANGAEA.548631, 2006ar.

Graf, W. and Oerter, H.: Density, d18O, deuterium, and tritium of firn core FRI18C90_330, In supplement to: Graf, Wolfgang; Moser, Heribert; Reinwarth, Oskar; Kipfstuhl, Sepp; Oerter, Hans; Minikin, Andreas; Wagenbach, Dietmar (1994): Snow-accumulation rates and isotopic content $(2 \mathrm{H}, 3 \mathrm{H})$ of near-surface firn from the Filchner-Ronne Ice Shelf, Antarctica, Ann. Glaciol., 20, 121-128, hdl:10013/epic.11645.d001, https://doi.org/10.1594/PANGAEA.548633, 2006as.

Graf, W. and Oerter, H.: Density, d180, deuterium, and tritium of firn core FRI19C90_05, In supplement to: Graf, Wolfgang; Moser, Heribert; Reinwarth, Oskar; Kipfstuhl, Sepp; Oerter, Hans; Minikin, Andreas; Wagenbach, Dietmar (1994): Snow-accumulation rates and isotopic content $(2 \mathrm{H}, 3 \mathrm{H})$ of near-surface firn from the Filchner-Ronne Ice Shelf, Antarctica, Ann. Glaciol., 20, 121-128, hdl:10013/epic.11645.d001, https://doi.org/10.1594/PANGAEA.548634, 2006at.

Graf, W. and Oerter, H.: High resolution density, conductivity, deuterium, and d18O of ice core FRI12C92_15, In supplement to: Graf, Wolfgang; Moser, Heribert; Reinwarth, Oskar; Kipfstuhl, Sepp; Oerter, Hans; Minikin, Andreas; Wagenbach, Dietmar (1994): Snow-accumulation rates and isotopic content $(2 \mathrm{H}, 3 \mathrm{H})$ of near-surface firn from the Filchner-Ronne Ice Shelf, Antarctica, Ann. Glaciol., 20, 121-128, hdl:10013/epic.11645.d001, https://doi.org/10.1594/PANGAEA.548744, 2006au.

Graf, W., Moser, H., Oerter, H., Reinwarth, O., and Stichler, W.: Annual means of density, d18O, and accumulation rates of ice core FRI07C84_340, In supplement to: Graf, W et al. (1988): Accumulation and ice core-studies on Filchner-Ronne Ice Shelf, Antarctica, Ann. Glaciol., 11, 23-31, hdl:10013/epic.25953.d001, https://doi.org/10.1594/PANGAEA.549170, 1988a.

Graf, W., Moser, H., Oerter, H., Reinwarth, O., and Stichler, W.: Annual means of density, d180, and accumulation rates of snow pit FRI05S86_240, In supplement to: Graf, W et al. (1988): Accumulation and ice core-studies on Filchner-Ronne Ice Shelf, Antarctica, Ann. Glaciol., 11, 23-31, hdl:10013/epic.25953.d001, https://doi.org/10.1594/PANGAEA.548930, 1988b.

Graf, W., Moser, H., Oerter, H., Reinwarth, O., and Stichler, W.: Density and d180 of snow pit FRI01S84_141, In supplement to: Graf, W et al. (1988): Accumulation and ice core-studies on Filchner-Ronne Ice Shelf, Antarctica, Ann. Glaciol., 11, 23-31, hdl:10013/epic.25953.d001, https://doi.org/10.1594/PANGAEA.548909, 1988c.

Graf, W., Moser, H., Oerter, H., Reinwarth, O., and Stichler, W.: Density and d180 of snow pit FRI03S86_345, 
In supplement to: Graf, W et al. (1988): Accumulation and ice core-studies on Filchner-Ronne Ice Shelf, Antarctica, Ann. Glaciol., 11, 23-31, hdl:10013/epic.25953.d001, https://doi.org/10.1594/PANGAEA.548910, 1988d.

Graf, W., Moser, H., Oerter, H., Reinwarth, O., and Stichler, W.: Density and d180 of snow pit FRI04S84_140, In supplement to: Graf, W et al. (1988): Accumulation and ice core-studies on Filchner-Ronne Ice Shelf, Antarctica, Ann. Glaciol., 11, 23-31, hdl:10013/epic.25953.d001, https://doi.org/10.1594/PANGAEA.548911, 1988e.

Graf, W., Moser, H., Oerter, H., Reinwarth, O., and Stichler, W.: Density and d180 of snow pit FRI05S84_240, In supplement to: Graf, W et al. (1988): Accumulation and ice core-studies on Filchner-Ronne Ice Shelf, Antarctica, Ann. Glaciol., 11, 23-31, hdl:10013/epic.25953.d001, https://doi.org/10.1594/PANGAEA.548912, 1988f.

Graf, W., Moser, H., Oerter, H., Reinwarth, O., and Stichler, W.: Density and d180 of snow pit FRI06S84_241, In supplement to: Graf, W et al. (1988): Accumulation and ice core-studies on Filchner-Ronne Ice Shelf, Antarctica, Ann. Glaciol., 11, 23-31, hdl:10013/epic.25953.d001, https://doi.org/10.1594/PANGAEA.548915, 1988g.

Graf, W., Moser, H., Oerter, H., Reinwarth, O., and Stichler, W.: Density and d180 of snow pit FRI07S84_340, In supplement to: Graf, W et al. (1988): Accumulation and ice core-studies on Filchner-Ronne Ice Shelf, Antarctica, Ann. Glaciol., 11, 23-31, hdl:10013/epic.25953.d001, https://doi.org/10.1594/PANGAEA.548916, 1988h.

Graf, W., Moser, H., Oerter, H., Reinwarth, O., and Stichler, W.: Density and d18O of snow pit FRI07S86_340, In supplement to: Graf, W et al. (1988): Accumulation and ice core-studies on Filchner-Ronne Ice Shelf, Antarctica, Ann. Glaciol., 11, 23-31, hdl:10013/epic.25953.d001, https://doi.org/10.1594/PANGAEA.548917, 1988 .

Graf, W., Moser, H., Oerter, H., Reinwarth, O., and Stichler, W.: Density and d18O of snow pit FRI08S84_341, In supplement to: Graf, W et al. (1988): Accumulation and ice core-studies on Filchner-Ronne Ice Shelf, Antarctica, Ann. Glaciol., 11, 23-31, hdl:10013/epic.25953.d001, https://doi.org/10.1594/PANGAEA.548918, 1988j.

Graf, W., Moser, H., Oerter, H., Reinwarth, O., and Stichler, W.: Density and d18O of snow pit FRI08S86_341, In supplement to: Graf, W et al. (1988): Accumulation and ice core-studies on Filchner-Ronne Ice Shelf, Antarctica, Ann. Glaciol., 11, 23-31, hdl:10013/epic.25953.d001, https://doi.org/10.1594/PANGAEA.548919, 1988k.

Graf, W., Moser, H., Oerter, H., Reinwarth, O., and Stichler, W.: Density and d18O of snow pit FRI13S86_335, In supplement to: Graf, W et al. (1988): Accumulation and ice core-studies on Filchner-Ronne Ice Shelf, Antarctica, Ann. Glaciol., 11, 23-31, hdl:10013/epic.25953.d001, https://doi.org/10.1594/PANGAEA.548920, 19881.

Graf, W., Moser, H., Oerter, H., Reinwarth, O., and Stichler, W.: Density and d180 of snow pit FRI15S86_131, In supplement to: Graf, W et al. (1988): Accumulation and ice core-studies on Filchner-Ronne Ice Shelf, Antarctica, Ann. Glaciol., 11, 23-31, hdl:10013/epic.25953.d001, https://doi.org/10.1594/PANGAEA.548921, 1988m.
Graf, W., Moser, H., Oerter, H., Reinwarth, O., and Stichler, W.: Density and d180 of snow pit FRI16S86_230, In supplement to: Graf, W et al. (1988): Accumulation and ice core-studies on Filchner-Ronne Ice Shelf, Antarctica, Ann. Glaciol., 11, 23-31, hdl:10013/epic.25953.d001, https://doi.org/10.1594/PANGAEA.548922, 1988n.

Graf, W., Moser, H., Oerter, H., Reinwarth, O., and Stichler, W.: Density and d18O of snow pit FRI17S86_231, In supplement to: Graf, W et al. (1988): Accumulation and ice core-studies on Filchner-Ronne Ice Shelf, Antarctica, Ann. Glaciol., 11, 23-31, hdl:10013/epic.25953.d001, https://doi.org/10.1594/PANGAEA.548925, 1988 o.

Graf, W., Moser, H., Oerter, H., Reinwarth, O., and Stichler, W.: Density and d18O of snow pit FRI18S86_330, In supplement to: Graf, W et al. (1988): Accumulation and ice core-studies on Filchner-Ronne Ice Shelf, Antarctica, Ann. Glaciol., 11, 23-31, hdl:10013/epic.25953.d001, https://doi.org/10.1594/PANGAEA.548924, 1988p.

Graf, W., Moser, H., Oerter, H., Reinwarth, O., and Stichler, W.: Density and d18O of snow pit FRI0686S_241, In supplement to: Graf, W et al. (1988): Accumulation and ice core-studies on Filchner-Ronne Ice Shelf, Antarctica, Ann. Glaciol., 11, 23-31, hdl:10013/epic.25953.d001, https://doi.org/10.1594/PANGAEA.548914, 1988q.

Graf, W., Reinwarth, O., Oerter, H., Mayer, C., and Lambrecht, A.: Annual means of density, d180, and accumulation rates of firn core FRI23C95_16, In supplement to: Graf, W et al. (1999): Surface accumulation on Foundation Ice Stream, Antarctica, Ann. Glaciol., 29, 23-28, https://doi.org/10.3189/172756499781820987, https://doi.org/10.1594/PANGAEA.548504, 1999a.

Graf, W., Reinwarth, O., Oerter, H., Mayer, C., and Lambrecht, A.: Annual means of density, d18O, and accumulation rates of firn core FRI23C95_16, In supplement to: Graf, W et al. (1999): Surface accumulation on Foundation Ice Stream, Antarctica, Ann. Glaciol., 29, 23-28, https://doi.org/10.3189/172756499781820987, https://doi.org/10.1594/PANGAEA.548504, 1999 b.

Graf, W., Reinwarth, O., Oerter, H., Mayer, C. and Lambrecht, A.: Annual means of density, d180, and accumulation rates of firn core FRI25C95_14, In supplement to: Graf, W et al. (1999): Surface accumulation on Foundation Ice Stream, Antarctica, Ann. Glaciol., 29, 23-28, https://doi.org/10.3189/172756499781820987, https://doi.org/10.1594/PANGAEA.548506, 1999c.

Graf, W., Reinwarth, O., Oerter, H., Mayer, C., and Lambrecht, A.: Annual means of density, d18O, and accumulation rates of firn core FRI26C95_13, In supplement to: Graf, W et al. (1999): Surface accumulation on Foundation Ice Stream, Antarctica, Ann. Glaciol., 29, 23-28, https://doi.org/10.3189/172756499781820987, https://doi.org/10.1594/PANGAEA.548507, 1999d.

Graf, W., Reinwarth, O., Oerter, H., Mayer, C., and Lambrecht, A.: Annual means of density, d180, and accumulation rates of firn core FRI27C95_12, In supplement to: Graf, W et al. (1999): Surface accumulation on Foundation Ice Stream, Antarctica, Ann. Glaciol., 29, 23-28, https://doi.org/10.3189/172756499781820987, https://doi.org/10.1594/PANGAEA.548508, 1999e. 
Graf, W., Reinwarth, O., Oerter, H., Mayer, C., and Lambrecht, A.: Annual means of density, d180, and accumulation rates of firn core FRI28C95_11, In supplement to: Graf, W et al. (1999): Surface accumulation on Foundation Ice Stream, Antarctica, Ann. Glaciol., 29, 23-28, https://doi.org/10.3189/172756499781820987, https://doi.org/10.1594/PANGAEA.548509, $1999 \mathrm{f}$.

Graf, W., Reinwarth, O., Oerter, H., Mayer, C., and Lambrecht, A.: Annual means of density, d180, and accumulation rates of firn core FRI29C95_10, In supplement to: Graf, W et al. (1999): Surface accumulation on Foundation Ice Stream, Antarctica, Ann. Glaciol., 29, 23-28, https://doi.org/10.3189/172756499781820987, https://doi.org/10.1594/PANGAEA.548510, 1999g.

Graf, W., Reinwarth, O., Oerter, H., Mayer, C., and Lambrecht, A.: Annual means of density, d18O, and accumulation rates of firn core FRI29C95_10, In supplement to: Graf, W et al. (1999): Surface accumulation on Foundation Ice Stream, Antarctica, Ann. Glaciol., 29, 23-28, https://doi.org/10.3189/172756499781820987, https://doi.org/10.1594/PANGAEA.548510, 1999h.

Graf, W., Reinwarth, O., Oerter, H., Mayer, C., and Lambrecht, A.: Annual means of density, d180, and accumulation rates of firn core FRI33C95_06, In supplement to: Graf, W et al. (1999): Surface accumulation on Foundation Ice Stream, Antarctica, Ann. Glaciol., 29, 23-28, https://doi.org/10.3189/172756499781820987, https://doi.org/10.1594/PANGAEA.548512, 1999 i.

Graf, W., Reinwarth, O., Oerter, H., Mayer, C., and Lambrecht, A.: Annual means of density, d180, deuterium, and accumulation rates of firn core FRI34C95_03, In supplement to: Graf, W et al. (1999): Surface accumulation on Foundation Ice Stream, Antarctica, Ann. Glaciol., 29, 23-28, https://doi.org/10.3189/172756499781820987, https://doi.org/10.1594/PANGAEA.548513, 1999j.

Graf, W., Reinwarth, O., Oerter, H., Mayer, C., and Lambrecht, A.: Annual means of density, d180, deuterium, tritium, and accumulation rates of firn core FRI32C95_07, In supplement to: Graf, W et al. (1999): Surface accumulation on Foundation Ice Stream, Antarctica, Ann. Glaciol., 29, 23-28, https://doi.org/10.3189/172756499781820987, https://doi.org/10.1594/PANGAEA.548511, 1999k.

Graf, W., Reinwarth, O., Oerter, H., Mayer, C., and Lambrecht, A.: Annual means of density, d180, deuterium, tritium, and accumulation rates of firn core FRI35C95_01, In supplement to: Graf, W et al. (1999): Surface accumulation on Foundation Ice Stream, Antarctica, Ann. Glaciol., 29, 23-28, https://doi.org/10.3189/172756499781820987, https://doi.org/10.1594/PANGAEA.548514, 19991.

Graf, W., Reinwarth, O., Oerter, H., Mayer, C., and Lambrecht, A.: Annual means of density, d180, deuterium, tritium, and accumulation rates of firn core FRI38C95_04, In supplement to: Graf, W et al. (1999): Surface accumulation on Foundation Ice Stream, Antarctica, Ann. Glaciol., 29, 23-28, https://doi.org/10.3189/172756499781820987, https://doi.org/10.1594/PANGAEA.548515, 1999m.

Graf, W., Reinwarth, O., Oerter, H., Mayer, C., and Lambrecht, A.: Density and d18O of firn core FRI24C95_15, In supplement to: Graf, W et al. (1999): Surface accumu- lation on Foundation Ice Stream, Antarctica, Ann. Glaciol., 29, 23-28, https://doi.org/10.3189/172756499781820987, https://doi.org/10.1594/PANGAEA.548448, 1999n.

Graf, W., Reinwarth, O., Oerter, H., Mayer, C., and Lambrecht, A.: Density and d18O of firn core FRI25C95_14, In supplement to: Graf, W et al. (1999): Surface accumulation on Foundation Ice Stream, Antarctica, Ann. Glaciol., 29, 23-28, https://doi.org/10.3189/172756499781820987, https://doi.org/10.1594/PANGAEA.548449, 1999o.

Graf, W., Reinwarth, O., Oerter, H., Mayer, C., and Lambrecht, A.: Density and d18O of firn core FRI27C95_12, In supplement to: Graf, W et al. (1999): Surface accumulation on Foundation Ice Stream, Antarctica, Ann. Glaciol., 29, 23-28, https://doi.org/10.3189/172756499781820987, https://doi.org/10.1594/PANGAEA.548451, 1999p.

Graf, W., Reinwarth, O., Oerter, H., Mayer, C., and Lambrecht, A.: Density and d18O of firn core FRI28C95_11, In supplement to: Graf, W et al. (1999): Surface accumulation on Foundation Ice Stream, Antarctica, Ann. Glaciol., 29, 23-28, https://doi.org/10.3189/172756499781820987, https://doi.org/10.1594/PANGAEA.548452, 1999q.

Graf, W., Reinwarth, O., Oerter, H., Mayer, C., and Lambrecht, A.: Density and d180 of firn core FRI30C95_09, In supplement to: Graf, W et al. (1999): Surface accumulation on Foundation Ice Stream, Antarctica, Ann. Glaciol., 29, 23-28, https://doi.org/10.3189/172756499781820987, https://doi.org/10.1594/PANGAEA.548454, 1999r.

Graf, W., Reinwarth, O., Oerter, H., Mayer, C., and Lambrecht, A.: Density and d18O of firn core FRI31C95_08, In supplement to: Graf, W et al. (1999): Surface accumulation on Foundation Ice Stream, Antarctica, Ann. Glaciol., 29, 23-28, https://doi.org/10.3189/172756499781820987, https://doi.org/10.1594/PANGAEA.548455, 1999s.

Graf, W., Reinwarth, O., Oerter, H., Mayer, C., and Lambrecht, A.: Density and d18O of firn core FRI33C95_06, In supplement to: Graf, W et al. (1999): Surface accumulation on Foundation Ice Stream, Antarctica, Ann. Glaciol., 29, 23-28, https://doi.org/10.3189/172756499781820987, https://doi.org/10.1594/PANGAEA.548457, 1999t.

Graf, W., Reinwarth, O., Oerter, H., Mayer, C., and Lambrecht, A.: Density, d18O, and deuterium of firn core FRI36C95_02, In supplement to: Graf, W et al. (1999): Surface accumulation on Foundation Ice Stream, Antarctica, Ann. Glaciol., 29, 23-28, https://doi.org/10.3189/172756499781820987, https://doi.org/10.1594/PANGAEA.548460, 1999u.

Graf, W., Reinwarth, O., Oerter, H., Mayer, C., and Lambrecht, A.: Density, d180, and deuterium of firn core FRI37C95_05, In supplement to: Graf, W et al. (1999): Surface accumulation on Foundation Ice Stream, Antarctica, Ann. Glaciol., 29, 23-28, https://doi.org/10.3189/172756499781820987, https://doi.org/10.1594/PANGAEA.548461, 1999v.

Graf, W., Reinwarth, O., Oerter, H., Mayer, C., and Lambrecht, A.: Density, d18O, deuterium, and tritium of firn core FRI32C95_07, In supplement to: Graf, W et al. (1999): Surface accumulation on Foundation Ice Stream, Antarctica, Ann. Glaciol., 29, 23-28, https://doi.org/10.3189/172756499781820987, https://doi.org/10.1594/PANGAEA.548456, 1999w.

Graf, W., Reinwarth, O., Oerter, H., Mayer, C., and Lambrecht, A.: Density, d18O, deuterium, and tritium of firn core FRI35C95_01, 
In supplement to: Graf, W et al. (1999): Surface accumulation on Foundation Ice Stream, Antarctica, Ann. Glaciol., 29, 23-28, https://doi.org/10.3189/172756499781820987, https://doi.org/10.1594/PANGAEA.548459, 1999x.

Graf, W., Reinwarth, O., Oerter, H., Mayer, C., and Lambrecht, A.: Density, d180, deuterium, and tritium of firn core FRI38C95_04, In supplement to: Graf, W et al. (1999): Surface accumulation on Foundation Ice Stream, Antarctica, Ann. Glaciol., 29, 23-28, https://doi.org/10.3189/172756499781820987, https://doi.org/10.1594/PANGAEA.548462, 1999y.

Graf, W., Oerter, H., Reinwarth, O., Stichler, W., Wilhelms, F., Miller, H., and Mulvaney, R.: Density and stable oxygen isotopes of firn core DML02S98_13, In supplement to: Graf, W et al. (2002): Stable-isotope records from Dronning Maud Land, Antarctica, Ann. Glaciol., 35, 195-201, https://doi.org/10.3189/172756402781816492, https://doi.org/10.1594/PANGAEA.104876, 2002a.

Graf, W., Oerter, H., Reinwarth, O., Stichler, W., Wilhelms, F., Miller, H., and Mulvaney, R.: Density and stable oxygen isotopes of firn core DML05C98_32 (B32), In supplement to: Graf, W et al. (2002): Stable-isotope records from Dronning Maud Land, Antarctica, Ann. Glaciol., 35, 195-201, https://doi.org/10.3189/172756402781816492, https://doi.org/10.1594/PANGAEA.104862, 2002 b.

Graf, W., Oerter, H., Reinwarth, O., Stichler, W., Wilhelms, F., Miller, H., and Mulvaney, R.: Density and stable oxygen isotopes of firn core DML11C98_03, In supplement to: Graf, W et al. (2002): Stable-isotope records from Dronning Maud Land, Antarctica, Ann. Glaciol., 35, 195-201, https://doi.org/10.3189/172756402781816492, https://doi.org/10.1594/PANGAEA.104864, 2002c.

Graf, W., Oerter, H., Reinwarth, O., Stichler, W., Wilhelms, F., Miller, H., and Mulvaney, R.: Density and stable oxygen isotopes of firn core DML12C98_17, In supplement to: Graf, W et al. (2002): Stable-isotope records from Dronning Maud Land, Antarctica, Ann. Glaciol., 35, 195-201, https://doi.org/10.3189/172756402781816492, https://doi.org/10.1594/PANGAEA.104865, 2002d.

Graf, W., Oerter, H., Reinwarth, O., Stichler, W., Wilhelms, F., Miller, H., and Mulvaney, R.: Density and stable oxygen isotopes of firn core DML13C98_16, In supplement to: Graf, W et al. (2002): Stable-isotope records from Dronning Maud Land, Antarctica, Ann. Glaciol., 35, 195-201, https://doi.org/10.3189/172756402781816492, https://doi.org/10.1594/PANGAEA.104866, 2002e.

Graf, W., Oerter, H., Reinwarth, O., Stichler, W., Wilhelms, F., Miller, H., and Mulvaney, R.: Density and stable oxygen isotopes of firn core DML14C98_15, In supplement to: Graf, W et al. (2002): Stable-isotope records from Dronning Maud Land, Antarctica, Ann. Glaciol., 35, 195-201, https://doi.org/10.3189/172756402781816492, https://doi.org/10.1594/PANGAEA.104867, $2002 \mathrm{f}$.

Graf, W., Oerter, H., Reinwarth, O., Stichler, W., Wilhelms, F., Miller, H., and Mulvaney, R.: Density and stable oxygen isotopes of firn core DML15C98_14, In supplement to: Graf, W et al. (2002): Stable-isotope records from Dronning Maud Land, Antarctica, Ann. Glaciol., 35, 195-201, https://doi.org/10.3189/172756402781816492, https://doi.org/10.1594/PANGAEA.104868, 2002g.
Graf, W., Oerter, H., Reinwarth, O., Stichler, W., Wilhelms, F., Miller, H., and Mulvaney, R.: Density and stable oxygen isotopes of firn core DML17C98_33 (B33), In supplement to: Graf, W et al. (2002): Stable-isotope records from Dronning Maud Land, Antarctica, Ann. Glaciol., 35, 195-201, https://doi.org/10.3189/172756402781816492, https://doi.org/10.1594/PANGAEA.104869, 2002h.

Graf, W., Oerter, H., Reinwarth, O., Stichler, W., Wilhelms, F., Miller, H., and Mulvaney, R.: Density and stable oxygen isotopes of firn core DML18C98_04, In supplement to: Graf, W et al. (2002): Stable-isotope records from Dronning Maud Land, Antarctica, Ann. Glaciol., 35, 195-201, https://doi.org/10.3189/172756402781816492, https://doi.org/10.1594/PANGAEA.104870, $2002 \mathrm{i}$.

Graf, W., Oerter, H., Reinwarth, O., Stichler, W., Wilhelms, F., Miller, H., and Mulvaney, R.: Density and stable oxygen isotopes of firn core DML20C98_08, In supplement to: Graf, W et al. (2002): Stable-isotope records from Dronning Maud Land, Antarctica, Ann. Glaciol., 35, 195-201, https://doi.org/10.3189/172756402781816492, https://doi.org/10.1594/PANGAEA.104872, 2002j.

Graf, W., Oerter, H., Reinwarth, O., Stichler, W., Wilhelms, F., Miller, H., and Mulvaney, R.: Density and stable oxygen isotopes of firn core DML22C98_11, In supplement to: Graf, W et al. (2002): Stable-isotope records from Dronning Maud Land, Antarctica, Ann. Glaciol., 35, 195-201, https://doi.org/10.3189/172756402781816492, https://doi.org/10.1594/PANGAEA.104874, 2002k.

Graf, W., Oerter, H., Reinwarth, O., Stichler, W., Wilhelms, F., Miller, H., and Mulvaney, R.: Density and stable oxygen isotopes of firn core DML23C98_12, In supplement to: Graf, W et al. (2002): Stable-isotope records from Dronning Maud Land, Antarctica, Ann. Glaciol., 35, 195-201, https://doi.org/10.3189/172756402781816492, https://doi.org/10.1594/PANGAEA.104875, 20021.

Graf, W., Oerter, H., Reinwarth, O., Stichler, W., Wilhelms, F., Miller, H., and Mulvaney, R.: Physical properties of firn core DML25C00_01, In supplement to: Graf, W et al. (2002): Stable-isotope records from Dronning Maud Land, Antarctica, Ann. Glaciol., 35, 195-201, https://doi.org/10.3189/172756402781816492, https://doi.org/10.1594/PANGAEA.58443, 2002m.

Graf, W., Oerter, H., Reinwarth, O., Stichler, W., Wilhelms, F., Miller, H., and Mulvaney, R.: Physical properties of firn core DML27C00_04, In supplement to: Graf, W et al. (2002): Stable-isotope records from Dronning Maud Land, Antarctica, Ann. Glaciol., 35, 195-201, https://doi.org/10.3189/172756402781816492, https://doi.org/10.1594/PANGAEA.58445, 2002n.

Graf, W., Oerter, H., Reinwarth, O., Stichler, W., Wilhelms, F., Miller, H., and Mulvaney, R.: Physical properties of firn core NM03C95_06, In supplement to: Graf, W et al. (2002): Stable-isotope records from Dronning Maud Land, Antarctica, Ann. Glaciol., 35, 195-201, https://doi.org/10.3189/172756402781816492, https://doi.org/10.1594/PANGAEA.58791, 2002 o.

Haas, C., Beckers, J., King, J., Silis, A., Stroeve, J., Wilkinson, J., Notenboom, B., Schweiger, A., and Hendricks, S.: Ice and Snow Thickness Variability and Change in the High Arctic Ocean Ob- 
served by In Situ Measurements, Geophys. Res. Lett., 44, 1046210469, https://doi.org/10.1002/2017GL075434, 2017.

Hall, D. K., Comiso, J. C., DiGirolamo, N. E., Shuman, C. A., Box, J. E., and Koenig, L. S.: Variability in the surface temperature and melt extent of the Greenland ice sheet from MODIS, Geophys. Res. Lett., 40, 2114-2120, https://doi.org/10.1002/grl.50240, 2013.

Harper, J., Humphrey, N., Pfeffer, W. T., Brown, J., and Fettweis, X.: Greenland ice-sheet contribution to sea-level rise buffered by meltwater storage in firn, Nature, 491, 240-243, https://doi.org/10.1038/nature11566, 2012.

Hawley, R. L., Courville, Z. R., Kehrl, L. M., Lutz, E. R., Osterberg, E. C., Overly, T. B., and Wong, G. J.: Recent accumulation variability in northwest Greenland from ground-penetrating radar and shallow cores along the Greenland Inland Traverse, J. Glaciol., 60, 375-382, https://doi.org/10.3189/2014JoG13J141, 2014.

Helm, V., Humbert, A., and Miller, H.: Elevation and elevation change of Greenland and Antarctica derived from CryoSat2, The Cryosphere, 8, 1539-1559, https://doi.org/10.5194/tc-81539-2014, 2014a.

Helm, V., Humbert, A., and Miller, H.: Elevation Model of Greenland derived from CryoSat-2 in the period 2011 to 2013, links to DEM and uncertainty map as GeoTIFF, In supplement to: Helm, V et al. (2014): Elevation and elevation change of Greenland and Antarctica derived from CryoSat-2, The Cryosphere, 8, 1539-1559, https://doi.org/10.5194/tc-8-15392014, https://doi.org/10.1594/PANGAEA.831393, 2014b.

Herron, M. M. and Langway, C. C.: Firn Densification: An Empirical Model, J. Glaciol., 25, 373-385, https://doi.org/10.3189/S0022143000015239, 1980.

Hofer, S., Tedstone, A. J., Fettweis, X., and Bamber, J. L.: Decreasing cloud cover drives the recent mass loss on the Greenland Ice Sheet, Science Advances, 3, e1700584, https://doi.org/10.1126/sciadv.1700584, 2017.

Hörhold, M. W., Kipfstuhl, S., Wilhelms, F., Freitag, J., and Frenzel, A.: The densification of layered polar firn, J. Geophys. Res., 116, F01001, https://doi.org/10.1029/2009JF001630, 2011.

Hubbard, B., Tison, J.-L., Philippe, M., Heene, B., Pattyn, F., Malone, T., and Freitag, J.: Ice shelf density reconstructed from optical televiewer borehole logging, Geophys. Res. Lett., 40, 58825887, https://doi.org/10.1002/2013GL058023, 2013.

IMBIE Team: Mass balance of the Antarctic Ice Sheet from 1992 to 2017, Nature, 558, 219-222, https://doi.org/10.1038/s41586018-0179-y, 2018.

King, J., Howell, S., Derksen, C., Rutter, N., Toose, P., Beckers, J. F., Haas, C., Kurtz, N., and Richter-Menge, J.: Evaluation of Operation IceBridge quick-look snow depth estimates on sea ice, Geophys. Res. Lett., 42, 9302-9310, https://doi.org/10.1002/2015GL066389, 2015.

Koenig, L. and Brucker, L.: Satellite-Era Accumulation Traverse 2011 (SEAT11) snowpit density data., 2011.

Koenig, L., Box, J., and Kurtz, N.: Improving Surface Mass Balance Over Ice Sheets and Snow Depth on Sea Ice, Eos T. Am. Geophys. Un., 94, 100-100, https://doi.org/10.1002/2013EO100006, 2013.

Koenig, L. S., Miège, C., Forster, R. R., and Brucker, L.: Initial in situ measurements of perennial meltwater storage in the Greenland firn aquifer, Geophys. Res. Lett., 41, 81-85, https://doi.org/10.1002/2013GL058083, 2014.

Koenig, L. S., Ivanoff, A., Alexander, P. M., MacGregor, J. A., Fettweis, X., Panzer, B., Paden, J. D., Forster, R. R., Das, I., McConnell, J. R., Tedesco, M., Leuschen, C., and Gogineni, P.: Annual Greenland accumulation rates (2009-2012) from airborne snow radar, The Cryosphere, 10, 1739-1752, https://doi.org/10.5194/tc-10-1739-2016, 2016.

Kreutz, K.: Microparticle, Conductivity, and Density Measurements from the WAIS Divide Deep Ice Core, Antarctica, U.S. Antarctic Program Data Center, https://doi.org/10.7265/N5K07264, 2011.

Kuipers Munneke, P., Ligtenberg, S. R. M., Noël, B. P. Y., Howat, I. M., Box, J. E., Mosley-Thompson, E., McConnell, J. R., Steffen, K., Harper, J. T., Das, S. B., and van den Broeke, M. R.: Elevation change of the Greenland Ice Sheet due to surface mass balance and firn processes, 1960-2014, The Cryosphere, 9, 2009-2025, https://doi.org/10.5194/tc-9-2009-2015, 2015.

Kurtz, N.: IceBridge Sea Ice Freeboard, Snow Depth, and Thickness, Version 1, National Snow and Ice Data Center, https://doi.org/10.5067/7XJ9HRV50O57, 2012.

Kwok, R., Kurtz, N. T., Brucker, L., Ivanoff, A., Newman, T., Farrell, S. L., King, J., Howell, S., Webster, M. A., Paden, J., Leuschen, C., MacGregor, J. A., Richter-Menge, J., Harbeck, J., and Tschudi, M.: Intercomparison of snow depth retrievals over Arctic sea ice from radar data acquired by Operation IceBridge, The Cryosphere, 11, 2571-2593, https://doi.org/10.5194/tc-112571-2017, 2017.

Laepple, T., Hörhold, M., Münch, T., Freitag, J., Wegner, A., and Kipfstuhl, S.: Layering of surface snow and firn at Kohnen Station, Antarctica: Noise or seasonal signal?, J. Geophys. Res.Earth, 121, 1849-1860, https://doi.org/10.1002/2016JF003919, 2016.

Lewis, M. J., Tison, J. L., Weissling, B., Delille, B., Ackley, S. F., Brabant, F., and Xie, H.: Sea ice and snow cover characteristics during the winter-spring transition in the Bellingshausen Sea: An overview of SIMBA 2007, Deep-Sea Res. Pt. II, 58, 1019-1038, https://doi.org/10.1016/j.dsr2.2010.10.027, 2011.

Liston, G. E., Haehnel, R. B., Sturm, M., Hiemstra, C. A., Berezovskaya, S., and Tabler, R. D.: Simulating complex snow distributions in windy environments using SnowTran-3D, J. Glaciol., 53, 241-256, https://doi.org/10.3189/172756507782202865, 2007.

MacFerrin, M., Machguth, H., van As, D., Charalampidis, C., Stevens, M., Vandecrux, B., Heilig, A., Langen, P., Mottram, R., Fettweis, X., van den Broeke, M. R., Moussavi, M., and Abdalati, W.: Rapid expansion of Greenland's low-permeability ice slabs in a warming climate, Nature, in review, 2018.

McGrath, D., Colgan, W., Bayou, N., Muto, A., and Steffen, K.: Recent warming at Summit, Greenland: Global context and implications, Geophys. Res. Lett., 40, 2091-2096, https://doi.org/10.1002/grl.50456, 2013.

Machguth, H., MacFerrin, M., van As, D., Box, J. E., Charalampidis, C., Colgan, W., Fausto, R. S., Meijer, H. A. J., Mosley-Thompson, E., and van de Wal, R. S. W.: Greenland meltwater storage in firn limited by nearsurface ice formation, Nat. Clim. Change, 6, 390-393, https://doi.org/10.1038/nclimate2899, 2016a.

Machguth, H., Thomsen, H. H., Weidick, A., Ahlstrøm, A. P., Abermann, J., Andersen, M. L., Andersen, S. B., Bjørk, A. A., Box, 
J. E., Braithwaite, R. J., Bøggild, C. E., Citterio, M., Clement, P., Colgan, W., Fausto, R. S., Gleie, K., Gubler, S., Hasholt, B., Hynek, B., Knudsen, N. T., Larsen, S. H., Mernild, S. H., Oerlemans, J., Oerter, H., Olesen, O. B., Smeets, C. J. P. P., Steffen, K., Stober, M., Sugiyama, S., van As, D., Broeke, M. R. V. D., and van de Wal, R. S.: Greenland surface mass-balance observations from the ice-sheet ablation area and local glaciers, J. Glaciol., 62, 861-887, https://doi.org/10.1017/jog.2016.75, 2016b.

Matsuoka, K., Skoglund, A., and Roth, G.: Quantarctica, Norwegian Polar Institute, https://doi.org/10.21334/npolar.2018.8516e961, 2018.

Mayewski, P. and Dixon, D. A.: US International Trans-Antarctic Scientific Expedition (US ITASE) Glaciochemical Data, Version 2, US_ITASE_Core Info-SWE-Density_2013.xlsx, National Snow and Ice Data Center, Boulder, Colorado, USA, 2013.

Mayewski, P. and Whitlow, S.: Regional Survey of Greenland, 1988 - Snow Pit Data, Version 1.0, https://doi.org/10.5065/D6154F6J, 2009a.

Mayewski, P. and Whitlow, S.: Snow Pit and Ice Core Data from Southern Greenland, 1984, Version 1.0, https://doi.org/10.5065/D6S180MH, 2009b.

Mayewski, P. and Whitlow, S.: Snow Pit Data from Greenland Summit, 1987, Version 1.0, https://doi.org/10.5065/D63X84RQ, 2009c.

Mayewski, P. and Whitlow, S.: Snow Pit Data from Greenland Summit, 1989 to 1993, Version 1.0, https://doi.org/10.5065/D6NP22KX, 2009d.

McGrath, D., Colgan, W., Bayou, N., Muto, A., and Steffen, K.: Recent warming at Summit, Greenland: Global context and implications, Geophys. Res. Lett., 40, 2091-2096, https://doi.org/10.1002/grl.50456, 2013.

Medley, B., Joughin, I., Das, S. B., Steig, E. J., Conway, H., Gogineni, S., Criscitiello, A. S., McConnell, J. R., Smith, B. E., van den Broeke, M. R., Lenaerts, J. T. M., Bromwich, D. H., and Nicolas, J. P.: Airborne-radar and ice-core observations of annual snow accumulation over Thwaites Glacier, West Antarctica confirm the spatiotemporal variability of global and regional atmospheric models, Geophys. Res. Lett., 40, 3649-3654, https://doi.org/10.1002/grl.50706, 2013.

Miège, C., Forster, R. R., Box, J. E., Burgess, E. W., McConnell, J. R., Pasteris, D. R., and Spikes, V. B.: Southeast Greenland high accumulation rates derived from firn cores and ground-penetrating radar, Ann. Glaciol., 54, 322-332, https://doi.org/10.3189/2013AoG63A358, 2013.

Miller, H. and Schwager, M.: Density of ice core ngt37C95.2 from the North Greenland Traverse, PANGAEA, https://doi.org/10.1594/PANGAEA.57798, 2000a.

Miller, H. and Schwager, M.: Density of ice core ngt42C95.2 from the North Greenland Traverse, PANGAEA, https://doi.org/10.1594/PANGAEA.57655, 2000b.

Mock, S. J.: Accumulation patterns on the Greenland ice sheet, U.S. Army Materiel Command, Cold Regions Research \& Engineering Laboratory, Hanover, N.H., 18 pp., http://www.dtic.mil/docs/ citations/AD0661638, 1967a.

Mock, S. J.: Calculated Patterns of Accumulation on the Greenland Ice Sheet, J. Glaciol., 6, 795-803, https://doi.org/10.3189/S0022143000020104, $1967 \mathrm{~b}$.
Morris, E. M.: A theoretical analysis of the neutron scattering method of measuring snow and ice density, J. Geophys. Res., 113, F03019, https://doi.org/10.1029/2007JF000962, 2008.

Morris, E. M. and Wingham, D. J.: Densification of polar snow: Measurements, modeling, and implications for altimetry, J. Geophys. Res.-Earth, 119, 349-365, https://doi.org/10.1002/2013JF002898, 2014.

Mosley-Thompson, E., McConnell, J. R., Bales, R. C., Li, Z., Lin, P.-N., Steffen, K., Thompson, L. G., Edwards, R., and Bathke, D.: Local to regional-scale variability of annual net accumulation on the Greenland ice sheet from PARCA cores, J. Geophys. Res., 106, 33839-33851, https://doi.org/10.1029/2001JD900067, 2001.

Nghiem, S. V., Hall, D. K., Mote, T. L., Tedesco, M., Albert, M. R., Keegan, K., Shuman, C. A., DiGirolamo, N. E., and Neumann, G.: The extreme melt across the Greenland ice sheet in 2012, Geophys. Res. Lett., 39, L20502, https://doi.org/10.1029/2012GL053611, 2012.

Oerter, H.: Density of firn core DML28C01_00, Alfred Wegener Institute, Helmholtz Center for Polar and Marine Research, Bremerhaven, PANGAEA, https://doi.org/10.1594/PANGAEA.69513, 2002.

Oerter, H.: Annual means of $\mathrm{d} 18 \mathrm{O}$ and accumulation rates of snow pit DML76S05_11, https://doi.org/10.1594/PANGAEA.708113, 2008a.

Oerter, H.: Annual means of $\mathrm{d} 18 \mathrm{O}$ and accumulation rates of snow pit DML77S05_12, https://doi.org/10.1594/PANGAEA.708114, 2008b.

Oerter, H.: Annual means of $\mathrm{d} 18 \mathrm{O}$ and accumulation rates of snow pit DML78S05_13, https://doi.org/10.1594/PANGAEA.708115, 2008c.

Oerter, H.: Annual means of $\mathrm{d} 18 \mathrm{O}$ and accumulation rates of snow pit DML79S05_14, https://doi.org/10.1594/PANGAEA.708116, 2008d.

Oerter, H.: Annual means of $\mathrm{d} 18 \mathrm{O}$ and accumulation rates of snow pit DML80S05_15, https://doi.org/10.1594/PANGAEA.708117, 2008e.

Oerter, H.: Annual means of $\mathrm{d} 18 \mathrm{O}$ and accumulation rates of snow pit DML81S05_16, https://doi.org/10.1594/PANGAEA.708118, $2008 \mathrm{f}$.

Oerter, H.: Annual means of $\mathrm{d} 18 \mathrm{O}$ and accumulation rates of snow pit DML82S05_17, https://doi.org/10.1594/PANGAEA.708119, 2008g.

Oerter, H.: Annual means of $\mathrm{d} 18 \mathrm{O}$ and accumulation rates of snow pit DML83S05_18, https://doi.org/10.1594/PANGAEA.708120, 2008h.

Oerter, H.: Annual means of d 180 and accumulation rates of snow pit DML84S05_19, https://doi.org/10.1594/PANGAEA.708121, 2008 i.

Oerter, H.: Annual means of $\mathrm{d} 18 \mathrm{O}$ and accumulation rates of snow pit DML85S05_20, https://doi.org/10.1594/PANGAEA.708122, $2008 \mathrm{j}$.

Oerter, H.: Annual means of $\mathrm{d} 18 \mathrm{O}$ and accumulation rates of snow pit DML86S05_21, https://doi.org/10.1594/PANGAEA.708123, 2008k.

Oerter, H.: Annual means of $\mathrm{d} 18 \mathrm{O}$ and accumulation rates of snow pit DML87S05_22, https://doi.org/10.1594/PANGAEA.708124, 20081. 
Oerter, H.: Annual means of $\mathrm{d} 18 \mathrm{O}$ and accumulation rates of snow pit DML88S05_23, https://doi.org/10.1594/PANGAEA.708125, $2008 \mathrm{~m}$.

Oerter, H.: Annual means of $\mathrm{d} 18 \mathrm{O}$ and accumulation rates of snow pit DML89S05_24, https://doi.org/10.1594/PANGAEA.708126, $2008 n$.

Oerter, H.: Annual means of $\mathrm{d} 180$ and accumulation rates of snow pit DML90S05_25, https://doi.org/10.1594/PANGAEA.708127, 2008 o.

Oerter, H.: Density and $\mathrm{d} 180$ in $10 \mathrm{~cm}$ resolution of snow pit DML76S05_11, https://doi.org/10.1594/PANGAEA.708097, 2008p.

Oerter, H.: Density and $\mathrm{d} 180$ in $10 \mathrm{~cm}$ resolution of snow pit DML77S05_12, https://doi.org/10.1594/PANGAEA.708098, 2008q.

Oerter, H.: Density and $\mathrm{d} 180$ in $10 \mathrm{~cm}$ resolution of snow pit DML78S05_13, https://doi.org/10.1594/PANGAEA.708099, 2008r.

Oerter, H.: Density and $\mathrm{d} 180$ in $10 \mathrm{~cm}$ resolution of snow pit DML79S05_14, https://doi.org/10.1594/PANGAEA.708100, 2008s.

Oerter, H.: Density and $\mathrm{d} 18 \mathrm{O}$ in $10 \mathrm{~cm}$ resolution of snow pit DML80S05_15, https://doi.org/10.1594/PANGAEA.708101, $2008 \mathrm{t}$.

Oerter, H.: Density and $\mathrm{d} 180$ in $10 \mathrm{~cm}$ resolution of snow pit DML81S05_16, https://doi.org/10.1594/PANGAEA.708102, 2008u.

Oerter, H.: Density and $\mathrm{d} 18 \mathrm{O}$ in $10 \mathrm{~cm}$ resolution of snow pit DML82S05_17, https://doi.org/10.1594/PANGAEA.708103, 2008v.

Oerter, H.: Density and $\mathrm{d} 180$ in $10 \mathrm{~cm}$ resolution of snow pit DML83S05_18, https://doi.org/10.1594/PANGAEA.708104, 2008w.

Oerter, H.: Density and $\mathrm{d} 180$ in $10 \mathrm{~cm}$ resolution of snow pit DML84S05_19, https://doi.org/10.1594/PANGAEA.708105, 2008x.

Oerter, H.: Density and $\mathrm{d} 180$ in $10 \mathrm{~cm}$ resolution of snow pit DML85S05_20, https://doi.org/10.1594/PANGAEA.708106, 2008y.

Oerter, H.: Density and $\mathrm{d} 18 \mathrm{O}$ in $10 \mathrm{~cm}$ resolution of snow pit DML86S05_21, https://doi.org/10.1594/PANGAEA.708107, $2008 \mathrm{z}$.

Oerter, H.: Density and $\mathrm{d} 180$ in $10 \mathrm{~cm}$ resolution of snow pit DML87S05_22, https://doi.org/10.1594/PANGAEA.708108, 2008aa.

Oerter, H.: Density and $\mathrm{d} 180$ in $10 \mathrm{~cm}$ resolution of snow pit DML88S05_23, https://doi.org/10.1594/PANGAEA.708109, 2008ab.

Oerter, H.: Density and $\mathrm{d} 18 \mathrm{O}$ in $10 \mathrm{~cm}$ resolution of snow pit DML89S05_24, https://doi.org/10.1594/PANGAEA.708110, 2008ac.

Oerter, H.: Density and $\mathrm{d} 180$ in $10 \mathrm{~cm}$ resolution of snow pit DML90S05_25, https://doi.org/10.1594/PANGAEA.708111, 2008ad.

Oerter, H.: High resolution density and d180 of snow pit DML87S05_22, https://doi.org/10.1594/PANGAEA.708093, 2008ae.

Oerter, H., Graf, W., Wilhelms, F., Minikin, A., and Miller, H.: Physical properties of firn core DML01C97_00, In sup- plement to: Oerter, H et al. (1999): Accumulation studies on Amundsenisen, Dronning Maud Land, by means of tritium, DEP and stable isotope measurements: first results from the 1995/96 and 1996/97 field seasons, Ann. Glaciol., 29, 1-9, https://doi.org/10.3189/172756499781820914, https://doi.org/10.1594/PANGAEA.58434, 1999a.

Oerter, H., Graf, W., Wilhelms, F., Minikin, A., and Miller, H.: Physical properties of firn core DML03C97_00, In supplement to: Oerter, H et al. (1999): Accumulation studies on Amundsenisen, Dronning Maud Land, by means of tritium, DEP and stable isotope measurements: first results from the 1995/96 and 1996/97 field seasons, Ann. Glaciol., 29, 1-9, https://doi.org/10.3189/172756499781820914, https://doi.org/10.1594/PANGAEA.58794, 1999b.

Oerter, H., Graf, W., Wilhelms, F., Minikin, A., and Miller, H.: Physical properties of firn core DML04C97_00, In supplement to: Oerter, $\mathrm{H}$ et al. (1999): Accumulation studies on Amundsenisen, Dronning Maud Land, by means of tritium, DEP and stable isotope measurements: first results from the 1995/96 and 1996/97 field seasons, Ann. Glaciol., 29, 1-9, https://doi.org/10.3189/172756499781820914, https://doi.org/10.1594/PANGAEA.58436, 1999c.

Oerter, H., Graf, W., Wilhelms, F., Minikin, A., and Miller, H.: Physical properties of firn core DML05C97_00, In supplement to: Oerter, H et al. (1999): Accumulation studies on Amundsenisen, Dronning Maud Land, by means of tritium, DEP and stable isotope measurements: first results from the 1995/96 and 1996/97 field seasons, Ann. Glaciol., 29, 1-9, https://doi.org/10.3189/172756499781820914, https://doi.org/10.1594/PANGAEA.58795, 1999d.

Oerter, H., Graf, W., Wilhelms, F., Minikin, A., and Miller, H.: Physical properties of firn core DML06C97_00, In supplement to: Oerter, $H$ et al. (1999): Accumulation studies on Amundsenisen, Dronning Maud Land, by means of tritium, DEP and stable isotope measurements: first results from the 1995/96 and 1996/97 field seasons, Ann. Glaciol., 29, 1-9, https://doi.org/10.3189/172756499781820914, https://doi.org/10.1594/PANGAEA.58796, 1999e.

Oerter, H., Graf, W., Wilhelms, F., Minikin, A., and Miller, H.: Physical properties of firn core DML07C97_00, In supplement to: Oerter, $\mathrm{H}$ et al. (1999): Accumulation studies on Amundsenisen, Dronning Maud Land, by means of tritium, DEP and stable isotope measurements: first results from the 1995/96 and 1996/97 field seasons, Ann. Glaciol., 29, 1-9, https://doi.org/10.3189/172756499781820914, https://doi.org/10.1594/PANGAEA.58792, $1999 f$.

Oerter, H., Graf, W., Wilhelms, F., Minikin, A., and Miller, H.: Physical properties of firn core DML08C97_00, In supplement to: Oerter, $H$ et al. (1999): Accumulation studies on Amundsenisen, Dronning Maud Land, by means of tritium, DEP and stable isotope measurements: first results from the 1995/96 and 1996/97 field seasons, Ann. Glaciol., 29, 1-9, https://doi.org/10.3189/172756499781820914, https://doi.org/10.1594/PANGAEA.58440, 1999g.

Oerter, H., Graf, W., Wilhelms, F., Minikin, A., and Miller, H.: Physical properties of firn core DML09C97_00, In supplement to: Oerter, H et al. (1999): Accumulation studies on Amundsenisen, Dronning Maud Land, by means of tritium, DEP and stable isotope measurements: first re- 
sults from the 1995/96 and 1996/97 field seasons, Ann. Glaciol., 29, 1-9, https://doi.org/10.3189/172756499781820914, https://doi.org/10.1594/PANGAEA.58793, 1999h.

Oerter, H., Wilhelms, F., Jung-Rothenhäusler, F., Göktas, F., Miller, H., Graf, W., and Sommer, S.: Physical properties of firn core DML03C98_09, In supplement to: Oerter, $\mathrm{H}$ et al. (2000): Accumulation rates in Dronning Maud Land, Antarctica, as revealed by dielectricprofiling measurements of shallow firn cores, Ann. Glaciol., 30, 27-34, https://doi.org/10.3189/172756400781820705, https://doi.org/10.1594/PANGAEA.58410, 2000a.

Oerter, H., Wilhelms, F., Jung-Rothenhäusler, F., Göktas, F., Miller, H., Graf, W., and Sommer, S.: Physical properties of firn core DML05C98_06, In supplement to: Oerter, $H$ et al. (2000): Accumulation rates in Dronning Maud Land, Antarctica, as revealed by dielectricprofiling measurements of shallow firn cores, Ann. Glaciol., 30, 27-34, https://doi.org/10.3189/172756400781820705, https://doi.org/10.1594/PANGAEA.58407, 2000b.

Oerter, H., Wilhelms, F., Jung-Rothenhäusler, F., Göktas, F., Miller, H., Graf, W., and Sommer, S.: Physical properties of firn core DML05C98_07, In supplement to: Oerter, H et al. (2000): Accumulation rates in Dronning Maud Land, Antarctica, as revealed by dielectricprofiling measurements of shallow firn cores, Ann. Glaciol., 30, 27-34, https://doi.org/10.3189/172756400781820705, https://doi.org/10.1594/PANGAEA.58806, 2000c.

Oerter, H., Wilhelms, F., Jung-Rothenhäusler, F., Göktas, F., Miller, H., Graf, W., and Sommer, S.: Physical properties of firn core DML12C98_17, In supplement to: Oerter, $\mathrm{H}$ et al. (2000): Accumulation rates in Dronning Maud Land, Antarctica, as revealed by dielectricprofiling measurements of shallow firn cores, Ann. Glaciol., 30, 27-34, https://doi.org/10.3189/172756400781820705, https://doi.org/10.1594/PANGAEA.58418, 2000d.

Oerter, H., Wilhelms, F., Jung-Rothenhäusler, F., Göktas, F., Miller, H., Graf, W., and Sommer, S.: Physical properties of firn core DML16C98_13, In supplement to: Oerter, $H$ et al. (2000): Accumulation rates in Dronning Maud Land, Antarctica, as revealed by dielectricprofiling measurements of shallow firn cores, Ann. Glaciol., 30, 27-34, https://doi.org/10.3189/172756400781820705, https://doi.org/10.1594/PANGAEA.58414, $2000 \mathrm{e}$.

Oerter, H., Wilhelms, F., Jung-Rothenhäusler, F., Göktas, F., Miller, H., Graf, W., and Sommer, S.: Physical properties of firn core DML19C98_05, In supplement to: Oerter, H et al. (2000): Accumulation rates in Dronning Maud Land, Antarctica, as revealed by dielectricprofiling measurements of shallow firn cores, Ann. Glaciol., 30, 27-34, https://doi.org/10.3189/172756400781820705, https://doi.org/10.1594/PANGAEA.58406, $2000 f$.

Oerter, H., Wilhelms, F., Jung-Rothenhäusler, F., Göktas, F., Miller, H., Graf, W., and Sommer, S.: Physical properties of firn core DML21C98_10, In supplement to: Oerter, H et al. (2000): Accumulation rates in Dronning Maud Land, Antarctica, as revealed by dielectricprofiling measurements of shallow firn cores, Ann. Glaciol., 30, 27-34, https://doi.org/10.3189/172756400781820705, https://doi.org/10.1594/PANGAEA.58807, 2000g.
Oerter, H., Wilhelms, F., Jung-Rothenhäusler, F., Göktas, F., Miller, H., Graf, W., and Sommer, S.: Physical properties of firn core DML24C98_18, In supplement to: Oerter, H et al. (2000): Accumulation rates in Dronning Maud Land, Antarctica, as revealed by dielectricprofiling measurements of shallow firn cores, Ann. Glaciol., 30, 27-34, https://doi.org/10.3189/172756400781820705, https://doi.org/10.1594/PANGAEA.58419, 2000h.

Oerter, H., Wilhelms, F., Jung-Rothenhäusler, F., Göktas, F., Miller, H., Graf, W., and Sommer, S.: Physical properties of firn core DML60C98_02, In supplement to: Oerter, H et al. (2000): Accumulation rates in Dronning Maud Land, Antarctica, as revealed by dielectricprofiling measurements of shallow firn cores, Ann. Glaciol., 30, 27-34, https://doi.org/10.3189/172756400781820705, https://doi.org/10.1594/PANGAEA.58797, $2000 i$.

Oerter, H., Wilhelms, F., Jung-Rothenhäusler, F., Göktas, F., Miller, H., Graf, W., and Sommer, S.: Physical properties of firn core NM03C98_01, In supplement to: Oerter, $\mathrm{H}$ et al. (2000): Accumulation rates in Dronning Maud Land, Antarctica, as revealed by dielectricprofiling measurements of shallow firn cores, Ann. Glaciol., 30, 27-34, https://doi.org/10.3189/172756400781820705, https://doi.org/10.1594/PANGAEA.58799, 2000j.

Ohmura, A.: ETH Greenland Expedition I, progress report no. 1, April 1989 to February 1991, ETH Zürich, Department of Geography, Tech. Report, 108 pp., 1991.

Ohmura, A.: ETH Greenland expedition: progress report no. 2: April 1991 to October 1992, ETH Zürich, Department of Geography, Tech. Report, 94 pp., 1992.

Ohmura, A. and Reeh, N.: New precipitation and accumulation maps for Greenland, J. Glaciol., 37, 140-148, https://doi.org/10.3189/S0022143000042891, 1991.

Overly, T. B., Hawley, R. L., Helm, V., Morris, E. M., and Chaudhary, R. N.: Greenland annual accumulation along the EGIG line, 1959-2004, from ASIRAS airborne radar and neutronprobe density measurements, The Cryosphere, 10, 1679-1694, https://doi.org/10.5194/tc-10-1679-2016, 2016.

Philippe, M., Tison, J.-L., Fjøsne, K., Hubbard, B., Kjær, H. A., Lenaerts, J. T. M., Drews, R., Sheldon, S. G., De Bondt, K., Claeys, P., and Pattyn, F.: Annual layer thicknesses and age-depth (oldest estimate) of Derwael Ice Rise (IC12), Dronning Maud Land, East Antarctica, Supplement to: Philippe, M et al. (2016): Ice core evidence for a 20th century increase in surface mass balance in coastal Dronning Maud Land, East Antarctica, The Cryosphere, 10, 2501-2516, https://doi.org/10.5194/tc-10-25012016, https://doi.org/10.1594/PANGAEA.857574, 2016.

Reeh, N., Fisher, D. A., Koerner, R. M., and Clausen, H. B.: An empirical firn-densification model comprising ice lenses, Ann. Glaciol., 42, 101-106, https://doi.org/10.3189/172756405781812871, 2005.

Renaud, A.: Etude physiques et chimiques sur la glace de l'indlandsis du Groenland, Meddelelser om Groenland, 177, 100-107, 1959.

Richter-Menge, J., Overland, J. E., and Mathis, J. T.: Arctic Report Card: Update for 2016, LSU Law Center: Climate Change Law and Policy Project, 2016.

Schaller, C. F., Freitag, J., Kipfstuhl, S., Laepple, T., Steen-Larsen, H. C., and Eisen, O.: A representative density profile of the 
North Greenland snowpack, The Cryosphere, 10, 1991-2002, https://doi.org/10.5194/tc-10-1991-2016, 2016.

Schaller, C. F., Kipfstuhl, S., Steen-Larsen, H.-C., Freitag, J., and Eisen, O.: Spatial variability of density stratigraphy and melt features for two polar snowpacks in Greenland and East Antarctica, PANGAEA, https://doi.org/10.1594/PANGAEA.884003, 2017.

Schlosser, E. and Oerter, H.: Annual mean values of d18O of firn core NM02C89_01, In supplement to: Schlosser, E; Oerter, H (2002): Shallow firn cones from Neumayer, Ekströmisen, Antartica: a comparison of accumulation rates and stable-isotope ratios, Ann. Glaciol., 35, 91-96, https://doi.org/10.3189/172756402781816915, https://doi.org/10.1594/PANGAEA.690383, 2002a.

Schlosser, E. and Oerter, H.: Annual mean values of d180 and accumulation rate of ice core NM03C98_01, In supplement to: Schlosser, E; Oerter, H (2002): Shallow firn cones from Neumayer, Ekströmisen, Antartica: a comparison of accumulation rates and stable-isotope ratios, Ann. Glaciol., 35, 91-96, https://doi.org/10.3189/172756402781816915, https://doi.org/10.1594/PANGAEA.690397, 2002b.

Schlosser, E. and Oerter, H.: Density and d18O of firn core NM02C89_01, In supplement to: Schlosser, E; Oerter, H (2002): Shallow firn cones from Neumayer, Ekströmisen, Antartica: a comparison of accumulation rates and stable-isotope ratios, Ann. Glaciol., 35, 91-96, $\quad$ https://doi.org/10.3189/172756402781816915, https://doi.org/10.1594/PANGAEA.690382, 2002c.

Serreze, M. C. and Francis, J. A.: The Arctic on the fast track of change, Weather, 61, 65-69, https://doi.org/10.1256/wea.197.05, 2006.

Shepherd, A., Ivins, E. R., A, G., Barletta, V. R., Bentley, M. J., Bettadpur, S., Briggs, K. H., Bromwich, D. H., Forsberg, R., Galin, N., Horwath, M., Jacobs, S., Joughin, I., King, M. A., Lenaerts, J. T. M., Li, J., Ligtenberg, S. R. M., Luckman, A., Luthcke, S. B., McMillan, M., Meister, R., Milne, G., Mouginot, J., Muir, A., Nicolas, J. P., Paden, J., Payne, A. J., Pritchard, H., Rignot, E., Rott, H., Sørensen, L. S., Scambos, T. A., Scheuchl, B., Schrama, E. J. O., Smith, B., Sundal, A. V., van Angelen, J. H., van de Berg, W. J., Broeke, M. R. van den, Vaughan, D. G., Velicogna, I., Wahr, J., Whitehouse, P. L., Wingham, D. J., Yi, D., Young, D., and Zwally, H. J.: A Reconciled Estimate of Ice-Sheet Mass Balance, Science, 338, 1183-1189, https://doi.org/10.1126/science.1228102, 2012.

Spikes, V. B., Hamilton, G. S., Mayewski, P. A., Arcone, S., and Kaspari, S.: US International Trans-Antarctic Scientific Expedition (US ITASE): GPR Profiles and Accumulation Mapping, https://doi.org/10.7265/N5GH9FV6, 2005.

Sturm, M., Holmgren, J., and Perovich, D. K.: Winter snow cover on the sea ice of the Arctic Ocean at the Surface Heat Budget of the Arctic Ocean (SHEBA): Temporal evolution and spatial variability, J. Geophys. Res., 107, 8047, https://doi.org/10.1029/2000JC000400, 2002.

Thomas, E. R., van Wessem, J. M., Roberts, J., Isaksson, E., Schlosser, E., Fudge, T. J., Vallelonga, P., Medley, B., Lenaerts, J., Bertler, N., van den Broeke, M. R., Dixon, D. A., Frezzotti, M., Stenni, B., Curran, M., and Ekaykin, A. A.: Regional Antarctic snow accumulation over the past 1000 years, Clim. Past, 13, 1491-1513, https://doi.org/10.5194/cp-13-1491-2017, 2017.
Turner, K., Harris, C., Lindsay, J. M., Mahoney, A. R., Schaeffer, R., and Witte, C.: unpublished field observations, Ikaagivik Sikukun project, 2018a.

Turner, K., Ayre, M., Baadshaug, O., Clark, A., Alexeev, V., Doulgeris, A. P., Eicken, H., Gong, M., Jensen, D., Kjellman, S. E., Krivova, M., Lohse, J. P., Mahoney, A. R., Miller, K., Moorman, B., Ochwat, N., Olsen, I. L., Quigley, C., Romeyn, R., Shates, J., and St. Germain, S.: Unpublished field observations, INTPART Arctic Field Summer Schools: Norway-Canada-USA collaboration (NFR project 261786/H30) supported by NSF and Ukpeaġvik Iñupiat Corporation, 2018b.

Vandecrux, B., Fausto, R. S., Langen, P. L., Van As, D., MacFerrin, M., Colgan, W. T., Ingeman-Nielsen, T., Steffen, K., Jensen, N. S., Møller, M. T., and Box, J. E.: Drivers of Firn Density on the Greenland Ice Sheet Revealed by Weather Station Observations and Modelling, J. Geophys. Res.-Earth, 123, https://doi.org/10.1029/2017JF004597, online first, 2018.

van Angelen, J. H., Lenaerts, J. T. M., van den Broeke, M. R., Fettweis, X., and van Meijgaard, E.: Rapid loss of firn pore space accelerates 21 st century Greenland mass loss, Geophys. Res. Lett., 40, 2109-2113, https://doi.org/10.1002/grl.50490, 2013.

van den Broeke, M., Box, J., Fettweis, X., Hanna, E., Noël, B., Tedesco, M., van As, D., van de Berg, W. J., and van Kampenhout, L.: Greenland Ice Sheet Surface Mass Loss: Recent Developments in Observation and Modeling, Current Climate Change Reports, 3, 345-356, https://doi.org/10.1007/s40641-017-00848, 2017.

Vaughan, D. G. and Russell, J.: Compilation of surface mass balance measurements in Antarctica, British Antarctic Survey, Cambridge, UK, Internal Report, 56 pp., ES4/8/1/1997/1, 1997.

Vaughan, D. G., Marshall, G. J., Connolley, W. M., Parkinson, C., Mulvaney, R., Hodgson, D. A., King, J. C., Pudsey, C. J., and Turner, J.: Recent Rapid Regional Climate Warming on the Antarctic Peninsula, Climatic Change, 60, 243-274, https://doi.org/10.1023/A:1026021217991, 2003.

Velicogna, I., Sutterley, T. C., and Broeke, M. R. van den: Regional acceleration in ice mass loss from Greenland and Antarctica using GRACE time-variable gravity data, Geophys. Res. Lett., 41, 8130-8137, https://doi.org/10.1002/2014GL061052, 2014.

Verfaillie, D., Fily, M., Le Meur, E., Magand, O., Jourdain, B., Arnaud, L., and Favier, V.: Snow accumulation variability derived from radar and firn core data along a $600 \mathrm{~km}$ transect in Adelie Land, East Antarctic plateau, The Cryosphere, 6, 1345-1358, https://doi.org/10.5194/tc-6-1345-2012, 2012.

Wagenbach, D., Graf, W., Minikin, A., Trefzer, U., Kipfstuhl, S., Oerter, H., and Blindow, N.: Annual means of density, d180, deuterium, tritium, and accumulation rates of firn core BER01C90_01, In supplement to: Wagenbach, D et al. (1994): Reconnaissance of chemical and isotopic firn properties on top of Berkner Island, Antarctica, Ann. Glaciol., 20, 307-312, hdl:10013/epic.15271.d001, https://doi.org/10.1594/PANGAEA.548637, 1994a.

Wagenbach, D., Graf, W., Minikin, A., Trefzer, U., Kipfstuhl, S., Oerter, H., and Blindow, N.: Density and d18O of snow pit BER01S90_01, In supplement to: Wagenbach, $\mathrm{D}$ et al. (1994): Reconnaissance of chemical and isotopic firn properties on top of Berkner Island, Antarctica, Ann. Glaciol., 20, 307-312, hdl:10013/epic.15271.d001, https://doi.org/10.1594/PANGAEA.548653, 1994 b. 
Wagenbach, D., Graf, W., Minikin, A., Trefzer, U., Kipfstuhl, S., Oerter, H., and Blindow, N.: Density and d18O of snow pit BER02S90_02, In supplement to: Wagenbach, D et al. (1994): Reconnaissance of chemical and isotopic firn properties on top of Berkner Island, Antarctica, Ann. Glaciol., 20, 307-312, hdl:10013/epic.15271.d001, https://doi.org/10.1594/PANGAEA.548654, 1994c.

Wagenbach, D., Graf, W., Minikin, A., Trefzer, U., Kipfstuhl, S., Oerter, H., and Blindow, N.: Density, d18O, deuterium, and tritium of firn core BER02C90_02, In supplement to: Wagenbach, D et al. (1994): Reconnaissance of chemical and isotopic firn properties on top of Berkner Island, Antarctica, Ann. Glaciol., 20, 307-312, hdl:10013/epic.15271.d001, https://doi.org/10.1594/PANGAEA.548622, 1994d.

Wang, Y., Ding, M., van Wessem, J. M., Schlosser, E., Altnau, S., van den Broeke, M. R., Lenaerts, J. T. M., Thomas, E. R., Isaksson, E., Wang, J., and Sun, W.: A Comparison of Antarctic Ice Sheet Surface Mass Balance from Atmospheric Climate Models and In Situ Observations, J. Climate, 29, 5317-5337, https://doi.org/10.1175/JCLI-D-15-0642.1, 2016.

Warren, S. G., Rigor, I. G., Untersteiner, N., Radionov, V. F., Bryazgin, N. N., Aleksandrov, Y. I., and Colony, R.: Snow Depth on Arctic Sea Ice, J. Climate, 12, 1814-1829, https://doi.org/10.1175/15200442(1999)012<1814:SDOASI>2.0.CO;2, 1999.
Webster, M. A., Rigor, I. G., Nghiem, S. V., Kurtz, N. T., Farrell, S. L., Perovich, D. K., and Sturm, M.: Interdecadal changes in snow depth on Arctic sea ice, J. Geophys. Res.-Oceans, 119, 53955406, https://doi.org/10.1002/2014JC009985, 2014.

Wilhelms, F.: Leitfähigkeits- und Dichtemessung an Eisbohrkernen/Measuring the Conductivity and Density of Ice Cores, Diplom thesis, Universität Bonn, Germany, 1996.

Wilhelms, F.: Density of ice core ngt03C93.2 from the North Greenland Traverse, PANGAEA, https://doi.org/10.1594/PANGAEA.56560, 2000a.

Wilhelms, F.: Density of ice core ngt06C93.2 from the North Greenland Traverse, PANGAEA, https://doi.org/10.1594/PANGAEA.57153, 2000 b.

Wilhelms, F.: Density of ice core ngt14C93.2 from the North Greenland Traverse, PANGAEA, https://doi.org/10.1594/PANGAEA.56615, 2000c.

Wilhelms, F.: Density of ice core ngt27C94.2 from the North Greenland Traverse, PANGAEA, https://doi.org/10.1594/PANGAEA.57296, 2000d.

Wilhelms, F.: Explaining the dielectric properties of firn as a density-and-conductivity mixed permittivity (DECOMP), Geophys. Res. Lett., 32, L16501, https://doi.org/10.1029/2005GL022808, 2005.

Zwally, H. J. and Jun, L.: Seasonal and interannual variations of firn densification and ice-sheet surface elevation at the Greenland summit, J. Glaciol., 48, 199-207, https://doi.org/10.3189/172756502781831403, 2002. 